Supporting Information

\title{
Discovery of Conformationally Constrained Tetracyclic Compounds as Potent Hepatitis C Virus NS5B RNA Polymerase Inhibitors
}

Kazutaka Ikegashira, ${ }^{*}{ }^{\dagger}$ Takahiro Oka, ${ }^{\dagger}$ Shintaro Hirashima, ${ }^{\dagger}$ Satoru Noji, ${ }^{\dagger}$ Hiroshi Yamanaka, ${ }^{\dagger}$ Yoshinori Hara ${ }^{\dagger}$ Tsuyoshi Adachi, ${ }^{\ddagger}$ Jun-Ichiro Tsuruha, ${ }^{\ddagger}$ Satoki Doi, ${ }^{\dagger}$ Yasunori Hase, ${ }^{\dagger}$ Toru Noguchi, ${ }^{\dagger}$ Izuru Ando, ${ }^{\dagger}$ Naoki Ogura, ${ }^{\dagger}$ Satoru Ikeda $^{\dagger}$ and Hiromasa Hashimoto*,†

${ }^{\dagger}$ Central Pharmaceutical Research Institute, Japan Tobacco Inc., 1-1 Murasaki-cho, Takatsuki, Osaka 569-1125, Japan

${ }^{\ddagger}$ Pharmaceutical Frontier Research Lab., Japan Tobacco Inc., 1-13-2 Fukuura, Kanazawa-ku, Yokohama, Kanagawa 236-0004, Japan

\section{Contents}

- Synthetic procedures and characterization data for the final compounds 3-20 $\quad$ S2-S19

- Computational method S20

- Crystallization and data measurement S20-S21

- Caco-2 assay S21-S22

- References S22 


\section{General Methods}

Solvents and reagents were obtained from commercial suppliers and used as received. Flash column chromatography was performed using Merck 230-400 mesh silica gel 60. Melting points were determined using a Yanagimoto micro melting point apparatus or a Büchi 535 melting point apparatus and are uncorrected. Proton nuclear magnetic resonance (1H NMR) spectra were recorded on a JEOL JNM-A300W, JEOL ALPHA300W, or Bruker AMX-300 spectrometer in the indicated solvent. Chemical shifts $(\delta)$ are reported in parts per million relative to internal standard tetramethylsilane. Combustion analyses were performed with a Perkin-Elmer 2402 series II CHNS/O analyzer. Low-resolution mass spectra (MS) analyses were performed on either a Finnigan TSQ-700 mass spectrometer in FAB ionization mode or an Agilent 1100 series LC/MSD mass spectrometer in ESI ionization mode. HPLC analyses were performed using either (A) a Shimazu LC10A, using a Shiseido CAPCELL PAK C18 VG120 column $(4.6 \mathrm{~mm} \times 150 \mathrm{~mm}$, solvent system $\mathrm{CH}_{3} \mathrm{CN}-0.1 \%$ TFA/ water- $0.1 \%$ TFA, gradient $25-90 \%$ over $18 \mathrm{~min}, 1 \mathrm{~mL} / \mathrm{min}, 40$ ${ }^{\circ}$ C), or (B) a Shimazu LC-2010C, using a Shiseido Guard Cartridge Capcell C18MG S-3 column $\left(1.0 \mathrm{~mm} \times 10 \mathrm{~mm}\right.$, solvent system $\mathrm{CH}_{3} \mathrm{CN} /$ water $/ 50 \mathrm{mM}$ aqueous ammonium acetate, gradient 5/90/5-95/0/5\% over $2 \mathrm{~min}, 0.8 \mathrm{~mL} / \mathrm{min}, 40^{\circ} \mathrm{C}$ ).

In vitro biochemical RdRp assays and the $\mathrm{HCV}$ replicon assays were carried out as previously described. ${ }^{1}$

\section{3-Benzyloxy-12-cyclohexyl-6,7-dihydro-5-oxa-7a-azadibenzo[a,e]azulene-9-carboxylic Acid (3).} Steps 1 and 2: Preparation of 2,4-Bismethoxymethyoxyphenylboronic Acid (22). To a solution of 2-bromoresorcinol $(30.00 \mathrm{~g}, 159.0 \mathrm{mmol})$ in acetone $(300 \mathrm{~mL})$ were added $\mathrm{K}_{2} \mathrm{CO}_{3}(66.00 \mathrm{~g}$, $471.0 \mathrm{mmol})$ and chloromethyl methyl ether $(30 \mathrm{~mL}, 397 \mathrm{mmol})$ with cooling by an ice-water bath. The mixture was stirred at room temperature for $22 \mathrm{~h}$. After the solvent was removed by evaporation in vacuo, water and EtOAc were added to the residue. The organic layer was separated, washed with brine and dried over $\mathrm{MgSO}_{4}$. Filtration and concentration in vacuo gave 1-bromo-2,4-bismethoxymethoxybenzene as a crude oil: ${ }^{1} \mathrm{H}$ NMR $\left(400 \mathrm{MHz}, \mathrm{CDCl}_{3}\right) \delta 7.39(\mathrm{~d}, \mathrm{~J}=$ $8.4 \mathrm{~Hz}, 1 \mathrm{H}), 6.85(\mathrm{~d}, \mathrm{~J}=2.8 \mathrm{~Hz}, 1 \mathrm{H}), 6.61(\mathrm{dd}, \mathrm{J}=2.8,8.8 \mathrm{~Hz}, 1 \mathrm{H}), 5.22(\mathrm{~s}, 2 \mathrm{H}), 5.13(\mathrm{~s}, 2 \mathrm{H}), 3.51$ $(\mathrm{s}, 3 \mathrm{H}), 3.46(\mathrm{~s}, 3 \mathrm{H})$.

To a solution of the crude oil obtained above in n-hexane $(250 \mathrm{~mL})$ and THF $(110 \mathrm{~mL})$ was added triisopropyl borate $(45.00 \mathrm{~g}, 238.0 \mathrm{mmol})$. After the solution was cooled with a dry ice-acetone bath 
$\left(-78{ }^{\circ} \mathrm{C}\right), 1.6 \mathrm{M}$ n-butyllithium in n-hexane $(151.0 \mathrm{~mL}, 238.0 \mathrm{mmol})$ was added dropwise. The mixture was stirred at $-78{ }^{\circ} \mathrm{C}$ for $5 \mathrm{~h}$. To the reaction mixture was added $1 \mathrm{~N}$ aqueous $\mathrm{HCl}$ with cooling by an ice-water bath and the mixture was stirred at the temperature for $15 \mathrm{~min}$. The mixture was extracted with EtOAc. The organic layer was separated, washed with brine and dried over $\mathrm{MgSO}_{4}$. Filtration and concentration in vacuo and purification by silica gel flash chromatography (n-hexane/EtOAc $=4 / 1)$ gave $13.60 \mathrm{~g}\left(35 \%\right.$ yield from 2-bromoresorcinol) of 22 as a solid: ${ }^{1} \mathrm{H}$ NMR (400MHz, $\left.\mathrm{CDCl}_{3}\right) \delta 7.75(\mathrm{~d}, \mathrm{~J}=8.4 \mathrm{~Hz}, 1 \mathrm{H}), 6.79(\mathrm{~d}, \mathrm{~J}=2.4 \mathrm{~Hz}, 1 \mathrm{H}), 6.75(\mathrm{dd}, \mathrm{J}=2.0,8.0$ $\mathrm{Hz}, 1 \mathrm{H}), 5.58$ (s, 2H), 5.27 (s, 2H), 5.19 (s, 2H), 3.50 (s, 2H), 3.48 (s, 3H).

\section{Step 3: Preparation of 2-(2,4-Bismethoxymethoxyphenyl)-3-cyclohexyl-1H-indole-6-carboxylic} Acid Methyl Ester (23). To a suspension of 22 (13.60 g, $56.2 \mathrm{mmol}$ ) obtained above and 2-bromo-3-cyclohexyl-1H-indole-6-carboxylic acid methyl ester $21^{2}$ (14.50 g, $\left.43.2 \mathrm{mmol}\right)$ in 1,2-dimethoxyethane (DME, $140 \mathrm{~mL})$ and $\mathrm{H}_{2} \mathrm{O}(70 \mathrm{~mL})$ were added $\mathrm{LiCl}(5.50 \mathrm{~g}, 129.0 \mathrm{mmol})$, $\mathrm{Na}_{2} \mathrm{CO}_{3}(13.70 \mathrm{~g}, 129.0 \mathrm{mmol})$ and tetrakis(triphenylphosphine)palladium(0) (5.00 g, $\left.4.3 \mathrm{mmol}\right)$. The mixture was heated at $90{ }^{\circ} \mathrm{C}$ for $22 \mathrm{~h}$. After the reaction mixture was cooled, the insoluble material was removed by filtration and EtOAc was added to the filtrate. The organic layer was separated, washed with saturated aqueous $\mathrm{NH}_{4} \mathrm{Cl}$ and brine, and dried over $\mathrm{MgSO}_{4}$. Filtration and concentration in vacuo and purification by silica gel flash chromatography (n-hexane/EtOAc $=3 / 1$ ) gave $16.90 \mathrm{~g}(86 \%)$ of 23 as an oil: ${ }^{1} \mathrm{H}$ NMR $\left(400 \mathrm{MHz}, \mathrm{CDCl}_{3}\right) \delta 8.38(\mathrm{~s}, 1 \mathrm{H}), 7.82(\mathrm{~d}, \mathrm{~J}=8.4 \mathrm{~Hz}$, 1H), $7.74(\mathrm{dd}, \mathrm{J}=1.2,8.4 \mathrm{~Hz}, 1 \mathrm{H}), 6.96(\mathrm{~d}, \mathrm{~J}=2.4 \mathrm{~Hz}, 1 \mathrm{H}), 6.83(\mathrm{dd}, \mathrm{J}=8.4,8.4 \mathrm{~Hz}, 1 \mathrm{H}), 5.22(\mathrm{~s}$, $2 \mathrm{H}), 5.12(\mathrm{~s}, 2 \mathrm{H}), 3.92(\mathrm{~s}, 3 \mathrm{H}), 3.53(\mathrm{~s}, 3 \mathrm{H}), 3.35(\mathrm{~s}, 3 \mathrm{H}), 2.73-2.86(\mathrm{~m}, 1 \mathrm{H}), 1.92-2.07(\mathrm{~m}, 2 \mathrm{H})$, $1.71-1.88(\mathrm{~m}, 5 \mathrm{H}), 1.26-1.41(\mathrm{~m}, 3 \mathrm{H})$; MS (FAB) $\mathrm{m} / \mathrm{z} 454(\mathrm{M}+\mathrm{H})^{+}$.

Steps 4-6: Preparation of 12 -Cyclohexyl-3-hydroxy-6,7-dihydro-5-oxa-7a-azabenzo[a,e] azulene-9-carboxylic Acid Methyl Ester (24).

To a solution of 23 (16.90 g, $37.3 \mathrm{mmol})$ in DMF (120 mL) was added NaH (2.10 g, $52.2 \mathrm{mmol}$, $60 \mathrm{wt} \%$ in mineral oil) with cooling by an ice-water bath and the mixture was stirred at the temperature for $20 \mathrm{~min}$. To the reaction mixture was added 2-(2-bromoethoxy)tetrahydro-2H-pyran $(8.5 \mathrm{~mL}, 55.9 \mathrm{mmol})$ with cooling by an ice-water bath and the mixture was stirred at room temperature for $4 \mathrm{~h}$. Saturated aqueous $\mathrm{NaHCO}_{3}$ was added to the reaction mixture and the mixture was extracted with EtOAc. The organic layer was washed with brine and dried over $\mathrm{MgSO}_{4}$. Filtration and concentration in vacuo gave 2-(2,4-bismethoxymethoxyphenyl)-3-cyclohexyl1-[2-(tetrahydropyran-2-yloxy)ethyl]-1H-indolecarboxylic acid methyl ester as a crude oil: ${ }^{1} \mathrm{H}$ NMR $\left(400 \mathrm{MHz}, \mathrm{CDCl}_{3}\right) \delta 8.21(\mathrm{~d}, \mathrm{~J}=5.2 \mathrm{~Hz}, 1 \mathrm{H}), 7.70-7.78(\mathrm{~m}, 2 \mathrm{H}), 7.11(\mathrm{dd}, \mathrm{J}=1.6,8.4 \mathrm{~Hz}, 1 \mathrm{H})$, 
$6.95(\mathrm{t}, \mathrm{J}=2.2 \mathrm{~Hz}, 1 \mathrm{H}), 6.78(\mathrm{dd}, \mathrm{J}=2.4,8.4 \mathrm{~Hz}, 1 \mathrm{H}), 5.23(\mathrm{~s}, 2 \mathrm{H}), 5.03$ (ddd, J = 1.5, 5.4, $15.6 \mathrm{~Hz}$, $2 \mathrm{H}), 4.33-4.40(\mathrm{~m}, 1 \mathrm{H}), 3.97-4.24(\mathrm{~m}, 3 \mathrm{H}), 3.92(\mathrm{~s}, 3 \mathrm{H}), 3.69-3.83(\mathrm{~m}, 2 \mathrm{H}), 3.54(\mathrm{~s}, 3 \mathrm{H})$, $3.42-3.53(\mathrm{~m}, 2 \mathrm{H}), 2.44-2.54(\mathrm{~m}, 1 \mathrm{H}), 1.22-1.90(\mathrm{~m}, 16 \mathrm{H})$.

To a solution of the crude oil obtained above in $\mathrm{MeOH}(525 \mathrm{~mL})$ and THF $(30 \mathrm{~mL})$ was added $6 \mathrm{~N}$ aqueous $\mathrm{HCl}(105 \mathrm{~mL})$ and the solution was stirred at room temperature for $10 \mathrm{~h}$. After the solvent was removed by evaporation in vacuo, water and EtOAc were added to the residue. The organic layer was separated, washed with brine and dried over $\mathrm{MgSO}_{4}$. Filtration and concentration in vacuo and purification by silica gel flash chromatography (n-hexane/EtOAc $=1 / 1)$ gave $10.30 \mathrm{~g}$ (68\% yield from 23) of 3-cyclohexyl-2-(2,4-dihydroxyphenyl)-1-(2-hydroxyethyl)-1H-indole6-carboxylic acid methyl ester as an oil: ${ }^{1} \mathrm{H}$ NMR $\left(400 \mathrm{MHz}, \mathrm{CDCl}_{3}\right) \delta 8.12(\mathrm{~s}, 1 \mathrm{H}), 7.76-7.83(\mathrm{~m}$, 2H), $7.00(\mathrm{~d}, \mathrm{~J}=8.0 \mathrm{~Hz}, 1 \mathrm{H}), 6.49-6.55(\mathrm{~m}, 2 \mathrm{H}), 5.67$ (brs, 1H), $5.18(\mathrm{~s}, 1 \mathrm{H}), 4.06-4.15$ (m, 2H), $3.94(\mathrm{~s}, 3 \mathrm{H}), 3.87-3.93(\mathrm{~m}, 1 \mathrm{H}), 3.73-3.81(\mathrm{~m}, 1 \mathrm{H}), 2.45-2.56(\mathrm{~m}, 1 \mathrm{H}), 1.63-1.84(\mathrm{~m}, 7 \mathrm{H})$, $1.20-1.29(\mathrm{~m}, 3 \mathrm{H})$.

To a solution of 3-cyclohexyl-2-(2,4-dihydroxyphenyl)-1-(2-hydroxyethyl)-1H-indole-6-carboxylic acid methyl ester $(10.30 \mathrm{~g}, 28.2 \mathrm{mmol})$ in THF $(500 \mathrm{~mL})$ were added triphenylphosphine $(7.30 \mathrm{~g}$, $27.7 \mathrm{mmol}$ ) and diethylazocarboxylate (DIPAD, $4.4 \mathrm{~mL}, 27.7 \mathrm{mmol}$ ) with cooling by an ice-water bath and the solution was stirred at room temperature for $4 \mathrm{~h}$. After the solvent was removed by evaporation in vacuo, the residue was purified by silica gel flash chromatography (n-hexane/EtOAc $=3 / 2)$ gave $6.50 \mathrm{~g}(66 \%)$ of 24 as a solid: ${ }^{1} \mathrm{H}$ NMR $\left(400 \mathrm{MHz}, \mathrm{CDCl}_{3}\right) \delta 8.04(\mathrm{~s}, 1 \mathrm{H}), 7.85(\mathrm{~d}, \mathrm{~J}=$ $8.4 \mathrm{~Hz}, 1 \mathrm{H}), 7.74(\mathrm{dd}, \mathrm{J}=1.2,8.4 \mathrm{~Hz}, 1 \mathrm{H}), 7.27$ (d, J = 8.4 Hz, 1H), 6.76 (dd, J = 2.4, 8.0 Hz, 1H), $6.72(\mathrm{~d}, \mathrm{~J}=2.4 \mathrm{~Hz}, 1 \mathrm{H}), 5.18(\mathrm{~s}, 1 \mathrm{H}), 4.48(\mathrm{t}, \mathrm{J}=5.6 \mathrm{~Hz}, 2 \mathrm{H}), 4.28(\mathrm{t}, \mathrm{J}=5.6 \mathrm{~Hz}, 2 \mathrm{H}), 3.94(\mathrm{~s}, 3 \mathrm{H})$, 2.87-2.97 (m, 1H), 1.98-2.12 (m, 2H), 1.74-1.90 (m, 5H), 1.29-1.43 (m, 3H); MS (FAB) m/z 392 $(\mathrm{M}+\mathrm{H})^{+}$.

Steps 7 and 8: Preparation of 3-Benzyloxy-12-cyclohexyl-6,7-dihydro-5-oxa-7a-azadibenzo [a,e]azulene-9-carboxylic Acid (3). To a solution of $24(150 \mathrm{mg}, 0.380 \mathrm{mmol})$ in DMF (2.0 mL) were added $\mathrm{K}_{2} \mathrm{CO}_{3}(132 \mathrm{mg}, 0.960 \mathrm{mmol})$ and benzyl bromide $(0.07 \mathrm{~mL}, 0.61 \mathrm{mmol})$, and the mixture was stirred at $60{ }^{\circ} \mathrm{C}$ for $3 \mathrm{~h}$. Saturated aqueous $\mathrm{NaHCO}_{3}$ was added to the reaction mixture and the mixture was extracted with EtOAc. The organic layer was washed with brine and dried over $\mathrm{MgSO}_{4}$. Filtration and concentration in vacuo and purification by silica gel flash chromatography (n-hexane/EtOAc = 3/1) gave $173 \mathrm{mg}(94 \%)$ of 3-benzyloxy-12-cyclohexyl-6,7-dihydro-5-oxa-7aazadibenzo[a,e]azulene-9-carboxylic acid methyl ester as a solid: ${ }^{1} \mathrm{H}$ NMR $\left(400 \mathrm{MHz}, \mathrm{CDCl}_{3}\right) \delta$ $8.03(\mathrm{~s}, 1 \mathrm{H}), 7.85(\mathrm{~d}, \mathrm{~J}=8.4 \mathrm{~Hz}, 1 \mathrm{H}), 7.73(\mathrm{dd}, \mathrm{J}=1.2,8.4 \mathrm{~Hz}, 1 \mathrm{H}), 7.25-7.48(\mathrm{~m}, 6 \mathrm{H}), 6.90(\mathrm{dd}, \mathrm{J}$ 
$=2.8,8.4 \mathrm{~Hz}, 1 \mathrm{H}), 6.85(\mathrm{~d}, \mathrm{~J}=2.4 \mathrm{~Hz}, 1 \mathrm{H}), 5.11(\mathrm{~s}, 2 \mathrm{H}), 4.49(\mathrm{t}, \mathrm{J}=5.6 \mathrm{~Hz}, 2 \mathrm{H}), 4.29(\mathrm{t}, \mathrm{J}=5.6$ $\mathrm{Hz}, 2 \mathrm{H}), 3.93$ (s, 3H), 2.88-2.98 (m, 1H), 1.99-2.12 (m, 2H), 1.75-1.90 (m, 5H), 1.30-1.43 (m, $3 \mathrm{H})$.

To a solution of 3-benzyloxy-12-cyclohexyl-6,7-dihydro-5-oxa-7a-azadibenzo[a,e]azulene-9carboxylic acid methyl ester (173 mg, $0.360 \mathrm{mmol})$ obtained above in $\mathrm{MeOH}(3.5 \mathrm{~mL})$ and THF $(3.5 \mathrm{~mL})$ was added $4 \mathrm{~N}$ aqueous $\mathrm{NaOH}(3.7 \mathrm{~mL})$ and the mixture was stirred at room temperature for $13 \mathrm{~h} .2 \mathrm{~N}$ aqueous $\mathrm{HCl}(3.7 \mathrm{ml})$ and water were added to the reaction mixture and the precipitates were collected by filtration. The solid was purified by silica gel flash chromatography (n-hexane/EtOAc $=1 / 1)$ gave $81 \mathrm{mg}(48 \%)$ of 3 as a solid: $\mathrm{mp} 265-267{ }^{\circ} \mathrm{C} ;{ }^{1} \mathrm{H}$ NMR $(300 \mathrm{MHz}$, DMSO-d $\left._{6}\right) \delta 12.54$ (brs, $\left.1 \mathrm{H}\right), 8.17(\mathrm{~d}, \mathrm{~J}=1.2 \mathrm{~Hz}, 1 \mathrm{H}), 7.86(\mathrm{~d}, \mathrm{~J}=8.4 \mathrm{~Hz}, 1 \mathrm{H}), 7.63$ (dd, J = 1.2, $8.4 \mathrm{~Hz}, 1 \mathrm{H}), 7.32-7.53(\mathrm{~m}, 6 \mathrm{H}), 7.03(\mathrm{dd}, \mathrm{J}=2.7,9.0 \mathrm{~Hz}, 1 \mathrm{H}), 6.92(\mathrm{~d}, \mathrm{~J}=2.4 \mathrm{~Hz}, 1 \mathrm{H}), 5.18$ (s, $2 \mathrm{H}), 4.41-4.49(\mathrm{~m}, 2 \mathrm{H}), 4.33-4.40(\mathrm{~m}, 2 \mathrm{H}), 2.79-2.93(\mathrm{~m}, 1 \mathrm{H}), 1.93-2.12(\mathrm{~m}, 2 \mathrm{H}), 1.68-1.87(\mathrm{~m}$, 5H), 1.24-1.45 (m, 3H); MS (FAB) m/z $468(\mathrm{M}+\mathrm{H})^{+}$. Anal. $\left(\mathrm{C}_{30} \mathrm{H}_{29} \mathrm{NO}_{4}\right) \mathrm{C}, \mathrm{H}, \mathrm{O}$.

\section{3-Cyclohexyl-6,7-dihydro-5H-benzo[3,4]azepino[1,2-a]indole-10-carboxylic Acid (7).}

Step 1: Preparation of 1-[3-(2-Bromophenyl)propyl]-3-cyclohexyl-1H-indole-6-carboxylic Acid Methyl Ester (27b). To a solution of 3-cyclohexyl-1H-indole-6-carboxylic acid methyl ester $25^{2}$ (500 mg, $1.94 \mathrm{mmol})$ in DMF (2.0 mL) was added $\mathrm{NaH}(93 \mathrm{mg}, 2.33 \mathrm{mmol}, 60 \mathrm{wt} \%$ in mineral oil) with cooling by an ice-water bath and the mixture was stirred for $30 \mathrm{~min}$. To the mixture was added a solution of 1-bromo-2-(3-iodopropyl)benzene $26 \mathrm{~b}^{3}(695 \mathrm{mg}, 2.14 \mathrm{mmol})$ in DMF $(1.5 \mathrm{~mL})$ at the temperature and the mixture was stirred at room temperature for $1 \mathrm{~h}$. Saturated aqueous $\mathrm{NH}_{4} \mathrm{Cl}$ was added to the reaction mixture and the mixture was extracted with EtOAc. The organic layer was washed with water and brine, and dried over $\mathrm{MgSO}_{4}$. Filtration and concentration in vacuo and purification by silica gel flash chromatography (n-hexane/EtOAc $=6 / 1)$ gave $770 \mathrm{mg}(79 \%)$ of $27 \mathrm{~b}$ as an oil: ${ }^{1} \mathrm{H}$ NMR $\left(400 \mathrm{MHz}, \mathrm{DMSO}_{\mathrm{d}}\right) \delta 8.03(\mathrm{~s}, 1 \mathrm{H}), 7.65(\mathrm{~d}, \mathrm{~J}=8.0 \mathrm{~Hz}, 1 \mathrm{H}), 7.60(\mathrm{dd}, \mathrm{J}=1.2$, $8.0 \mathrm{~Hz}, 1 \mathrm{H}), 7.54(\mathrm{~d}, \mathrm{~J}=7.6 \mathrm{~Hz}, 1 \mathrm{H}), 7.40(\mathrm{~s}, 1 \mathrm{H}), 7.27-7.33(\mathrm{~m}, 2 \mathrm{H}), 7.11-7.15(\mathrm{~m}, 1 \mathrm{H}), 4.27$ (t, J $=7.0 \mathrm{~Hz}, 2 \mathrm{H}), 3.85(\mathrm{~s}, 3 \mathrm{H}), 2.75-2.83(\mathrm{~m}, 1 \mathrm{H}), 2.67(\mathrm{dd}, \mathrm{J}=5.6,8.4 \mathrm{~Hz}, 2 \mathrm{H}), 1.92-2.10(\mathrm{~m}, 4 \mathrm{H})$, 1.69-1.84 (m, 3H), 1.37-1.50 (m, 4H), 1.21-1.32 (m, 1H).

Steps 2 and 3: Preparation of 13-Cyclohexyl-6,7-dihydro-5H-benzo[3,4]azepino[1,2-a]indole10-carboxylic Acid (7). To a solution of $27 \mathrm{~b}$ (250 $\mathrm{mg}, 0.550 \mathrm{mmol})$ in DMA (7.5 mL) were added AcOK (59 mg, $0.61 \mathrm{mmol}$ ) and tetrakis(triphenylphosphine)palladium(0) (32 mg, $0.028 \mathrm{mmol}$ ) and the mixture was heated at $160{ }^{\circ} \mathrm{C}$ for $5 \mathrm{~h}$. After cooling, the reaction mixture was poured into water 
and extracted with EtOAc. The organic layer was washed with water and brine, and dried over $\mathrm{MgSO}_{4}$. Filtration and concentration in vacuo and purification by silica gel flash chromatography (n-hexane/EtOAc $=8 / 1 \sim 4 / 1)$ gave $55 \mathrm{mg}$ (27\%) of 13-cyclohexyl-6,7-dihydro-5Hbenzo[3,4]azepino[1,2-a]indole-10-carboxylic acid methyl ester as a solid: ${ }^{1} \mathrm{H}$ NMR (400MHz, DMSO-d $\left._{6}\right) \delta 8.14(\mathrm{~d}, \mathrm{~J}=1.2 \mathrm{~Hz}, 1 \mathrm{H}), 7.89(\mathrm{~d}, \mathrm{~J}=8.0 \mathrm{~Hz}, 1 \mathrm{H}), 7.61(\mathrm{dd}, \mathrm{J}=1.6,8.4 \mathrm{~Hz}, 1 \mathrm{H})$, 7.37-7.46 (m, 4H), 4.56-4.65 (m, 1H), $3.87(\mathrm{~s}, 3 \mathrm{H}), 3.47-3.57(\mathrm{~m}, 1 \mathrm{H}), 2.77-2.88(\mathrm{~m}, 1 \mathrm{H})$, 2.66-2.75 (m, 1H), 2.27-2.41 (m, 2H), 1.12-2.08 (m, 10H); MS (FAB) m/z $374(\mathrm{M}+\mathrm{H})^{+}$.

To a solution of the benzo[3,4]azepino[1,2-a]indole-10-carboxylic acid methyl ester (55 mg, 0.15 mmol) obtained above in $\mathrm{MeOH}(2.0 \mathrm{~mL})$ and $\mathrm{THF}(2.0 \mathrm{~mL})$ was added $4 \mathrm{~N}$ aqueous $\mathrm{NaOH}(1.0$ $\mathrm{mL})$ and the mixture was stirred at $50{ }^{\circ} \mathrm{C}$ for $2 \mathrm{~h}$. After cooling, $2 \mathrm{~N}$ aqueous $\mathrm{HCl}(2.5 \mathrm{ml})$ and water were added to the reaction mixture and the precipitates were collected by filtration to give $44 \mathrm{mg}$ (83\%) of 7 as a solid: $\mathrm{mp}>300^{\circ} \mathrm{C} ;{ }^{1} \mathrm{H}$ NMR $(400 \mathrm{MHz}$, DMSO-d 6 ) $\delta 12.54$ (brs, $1 \mathrm{H}), 8.10$ (s, $\left.1 \mathrm{H}\right)$, $7.85(\mathrm{~d}, \mathrm{~J}=8.4 \mathrm{~Hz}, 1 \mathrm{H}), 7.60(\mathrm{~d}, \mathrm{~J}=8.4 \mathrm{~Hz}, 1 \mathrm{H}), 7.36-7.45(\mathrm{~m}, 4 \mathrm{H}), 4.53-4.62(\mathrm{~m}, 1 \mathrm{H}), 3.45-3.58$ (m, 1H), 2.77-2.88 (m, 1H), 2.65-2.75 (m, 1H), 2.27-2.42 (m, 2H), 1.11-2.10 (m, 10H); MS (FAB) $\mathrm{m} / \mathrm{z} 360(\mathrm{M}+\mathrm{H})^{+}$. Anal. $\left(\mathrm{C}_{24} \mathrm{H}_{25} \mathrm{NO}_{2} \cdot 0.1 \mathrm{H}_{2} \mathrm{O}\right) \mathrm{C}, \mathrm{H}, \mathrm{N}$.

\section{1-Cyclohexyl-6H-isoindolo[2,1-a]indole-3-carboxylic Acid (5).}

Compound 5 was prepared from $25^{2}$ and 2-bromobenzyl bromide using the procedure described above for 7: mp 285-287 ${ }^{\circ} \mathrm{C}$; ${ }^{1} \mathrm{H}$ NMR (400MHz, DMSO-d 6 ) $\delta 12.54(\mathrm{~s}, 1 \mathrm{H}), 8.03(\mathrm{~d}, \mathrm{~J}=1.2 \mathrm{~Hz}$, 1H), $7.91(\mathrm{~d}, \mathrm{~J}=7.7 \mathrm{~Hz}, 1 \mathrm{H}), 7.79(\mathrm{~d}, \mathrm{~J}=8.3 \mathrm{~Hz}, 1 \mathrm{H}), 7.61(\mathrm{~d}, \mathrm{~J}=7.7 \mathrm{~Hz}, 2 \mathrm{H}), 7.60(\mathrm{dd}, \mathrm{J}=1.4$, $8.6 \mathrm{~Hz}, 2 \mathrm{H}), 7.49$ (t, J = 7.2 Hz, 1H), 7.39 (t, J = 7.1 Hz, 1H), 5.25 (s, 2H), 3.24 (tt, J = 3.0, $11.7 \mathrm{~Hz}$, 1H), 2.01-1.75 (m, 7H), 1.58-1.40 (m, 3H); MS (FAB) m/z $332(\mathrm{M}+\mathrm{H})^{+}$. Anal. $\left(\mathrm{C}_{22} \mathrm{H}_{21} \mathrm{NO}_{2}\right) \mathrm{C}, \mathrm{H}, \mathrm{N}$.

12-Cyclohexyl-5,6-dihydroindolo[2,1-a]isoquinoline-9-carboxylic Acid (6). Steps 1 and 2: Preparation of 2-[2-(Tetrahydropyran-2-yloxy)ethyl]phenylboronic Acid (32). To a solution of 2-(2-bromophenyl)ethanol (3.10 g, $15.4 \mathrm{mmol})$ and p-toluenesulfonic acid monohydrate (10.0 $\mathrm{mg}$, $5.35 \mathrm{mmol})$ in $\mathrm{CHCl}_{3}(30.0 \mathrm{~mL})$ was added 3,4-dihydro-2H-pyran $(1.70 \mathrm{~mL}, 18.6 \mathrm{mmol})$ with cooling by an ice-water bath and the mixture was stirred at room temperature for $1 \mathrm{~h}$. Saturated aqueous $\mathrm{NaHCO}_{3}$ was added to the reaction mixture and the mixture was extracted with $\mathrm{CHCl}_{3}$. The organic layer was washed with brine and dried over $\mathrm{Na}_{2} \mathrm{SO}_{4}$. Filtration and concentration in vacuo and purification by silica gel flash chromatography (n-hexane/EtOAc $=30 / 1 \sim 10 / 1$ ) gave $3.58 \mathrm{~g}(81 \%)$ of 2-[2-(2-bromophenyl)ethoxy]tetrahydropyran as an oil: ${ }^{1} \mathrm{H} \mathrm{NMR}\left(400 \mathrm{MHz}, \mathrm{CDCl}_{3}\right)$ 
$\delta 7.53(\mathrm{dd}, \mathrm{J}=1.2,8.1 \mathrm{~Hz}, 1 \mathrm{H}), 7.30(\mathrm{dd}, \mathrm{J}=1.9,7.4 \mathrm{~Hz}, 1 \mathrm{H}), 7.23(\mathrm{dt}, \mathrm{J}=1.4,7.4 \mathrm{~Hz}, 1 \mathrm{H}), 7.07$ $(\mathrm{td}, \mathrm{J}=1.7,7.7 \mathrm{~Hz}, 1 \mathrm{H}), 4.61(\mathrm{t}, \mathrm{J}=3.7 \mathrm{~Hz}, 1 \mathrm{H}), 3.95(\mathrm{td}, \mathrm{J}=4.9,12.8 \mathrm{~Hz}, 1 \mathrm{H}), 3.79-3.73(\mathrm{~m}, 1 \mathrm{H})$, $3.65(\mathrm{td}, \mathrm{J}=4.9,12.8 \mathrm{~Hz}, 1 \mathrm{H}), 3.47-3.45(\mathrm{~m}, 1 \mathrm{H}), 3.07(\mathrm{t}, \mathrm{J}=7.2 \mathrm{~Hz}, 2 \mathrm{H}), 1.82-1.80(\mathrm{~m}, 1 \mathrm{H})$, $1.72-1.67(\mathrm{~m}, 1 \mathrm{H}), 1.57-1.53(\mathrm{~m}, 4 \mathrm{H})$.

To a solution of 2-[2-(2-bromophenyl)ethoxy]tetrahydropyran (3.58 g, $12.5 \mathrm{mmol})$ and triisopropyl borate $(3.70 \mathrm{~mL}, 16.1 \mathrm{mmol})$ in THF $(10.0 \mathrm{~mL})$ was added $1.6 \mathrm{M}$-butyllithium in $\mathrm{n}$-hexane (151 $\mathrm{mL}, 238 \mathrm{mmol}$ ) dropwise with cooling by a dry ice-acetone bath. The mixture was stirred at $0{ }^{\circ} \mathrm{C}$ for $2 \mathrm{~h}$. $1 \mathrm{~N}$ aqueous $\mathrm{HCl}$ was added to the reaction mixture and the mixture was extracted with EtOAc. The organic layer was washed with brine and dried over $\mathrm{Na}_{2} \mathrm{SO}_{4}$. Filtration and concentration in vacuo and purification by silica gel flash chromatography (n-hexane/EtOAc $=3 / 1$ 2/1) gave $1.77 \mathrm{~g}(56 \%)$ of 32 as an oil: ${ }^{1} \mathrm{H}$ NMR $\left(400 \mathrm{MHz}, \mathrm{CDCl}_{3}\right) \delta 7.67(\mathrm{~d}, \mathrm{~J}=7.4 \mathrm{~Hz}, 1 \mathrm{H})$, $7.38(\mathrm{t}, \mathrm{J}=7.7 \mathrm{~Hz}, 1 \mathrm{H}), 7.24-7.23(\mathrm{~m}, 2 \mathrm{H}), 6.42$ (brs, 2H), 4.60-4.58 (m, 1H), 4.34-4.31 (m, 1H), 3.71-3.66 (m, 1H), 3.36-3.33 (m, 2H), 3.05-3.01 (m, 2H), 1.66-1.26 (m, 4H), 0.95-0.90 (m, 2H).

Step 3: Preparation of 3-Cyclohexyl-2-\{2-[2-(tetrahydropyran-2-yloxy)ethyl]phenyl\}-1Hindole-6-carboxylic Acid Methyl Ester (28a). To a suspension of $21^{2}$ (2.10 g, $\left.6.24 \mathrm{mmol}\right)$ and 32 $(1.77 \mathrm{~g}, 7.10 \mathrm{mmol})$ in DME $(20 \mathrm{~mL})$ and water $(10 \mathrm{~mL})$ were added tetrakis(triphenylphosphine) palladium(0) (360 mg, $0.31 \mathrm{mmol})$ and $\mathrm{NaHCO}_{3}(2.00 \mathrm{~g}, 24.0 \mathrm{mmol})$, and the mixture was heated at reflux temperature for $7 \mathrm{~h}$. After cooling, water was added to the reaction mixture and the mixture was extracted with EtOAc. The organic layer was washed with water and brine, and dried over $\mathrm{Na}_{2} \mathrm{SO}_{4}$. Filtration and concentration in vacuo and purification by silica gel flash chromatography (n-hexane/EtOAc $=6 / 1 \sim 5 / 1)$ gave $2.21 \mathrm{~g}(77 \%)$ of $28 \mathrm{a}$ as an oil: $\mathrm{MS}(\mathrm{FAB}) \mathrm{m} / \mathrm{z} 462(\mathrm{M}+\mathrm{H})^{+}$.

Steps 4-6: Preparation of 12-Cyclohexyl-5,6-dihydroindolo[2, 1-a]isoquinoline-9-caboxylic Acid Methyl Ester (30a). To a solution of 28a (2.21 g, $4.80 \mathrm{mmol})$ in MeOH (10 mL) and THF (10 $\mathrm{mL})$ was added $6 \mathrm{~N}$ aqueous $\mathrm{HCl}(20 \mathrm{~mL})$ and the mixture was stirred at room temperature for $2 \mathrm{~h}$. Water was added to the reaction mixture and the mixture was extracted with EtOAc. The organic layer was washed with water, saturated aqueous $\mathrm{NaHCO}_{3}$ and brine, and dried over $\mathrm{Na}_{2} \mathrm{SO}_{4}$. Filtration and concentration in vacuo and purification by silica gel flash chromatography (n-hexane/EtOAc = 5/1 2/1) gave $1.20 \mathrm{~g}$ (67\%) of 3-cyclohexyl-2-[2-(2-hydroxyethyl)phenyl]-1Hindole-6-caboxylic acid methyl ester as an oil: ${ }^{1} \mathrm{H} \mathrm{NMR}\left(400 \mathrm{MHz}, \mathrm{CDCl}_{3}\right) \delta 9.85(\mathrm{~s}, 1 \mathrm{H}), 8.10(\mathrm{~s}$, $1 \mathrm{H}), 7.84(\mathrm{~d}, \mathrm{~J}=8.3 \mathrm{~Hz}, 1 \mathrm{H}), 7.76(\mathrm{dd}, \mathrm{J}=1.4,8.3 \mathrm{~Hz}, 1 \mathrm{H}), 7.46-7.31(\mathrm{~m}, 4 \mathrm{H}), 4.01-3.97$ (m, 2H), $3.94(\mathrm{~s}, 3 \mathrm{H}), 2.72-2.69(\mathrm{~m}, 3 \mathrm{H}), 1.98-1.80(\mathrm{~m}, 7 \mathrm{H}), 1.30-1.26(\mathrm{~m}, 3 \mathrm{H})$.

To a solution of the alcohol $(600 \mathrm{mg}, 1.58 \mathrm{mmol})$ obtained above in $\mathrm{CHCl}_{3}(6.0 \mathrm{~mL})$ were added 
$\mathrm{CBr}_{4}(790 \mathrm{mg}, 2.38 \mathrm{mmol})$ and triphenylphosphine $(497 \mathrm{mg}, 1.89 \mathrm{mmol})$ and the mixture was stirred at room temperature for $5 \mathrm{~min}$. Saturated aqueous $\mathrm{NaHCO}_{3}$ was added to the reaction mixture and the mixture was extracted with $\mathrm{CHCl}_{3}$. The organic layer was washed with brine and dried over $\mathrm{Na}_{2} \mathrm{SO}_{4}$. Filtration and concentration in vacuo and purification by silica gel flash chromatography (n-hexane/EtOAc $=7 / 1 \sim 6 / 1)$ gave $500 \mathrm{mg}(72 \%)$ of 2-[2-(2-bromoethyl)phenyl]3-cyclohexyl-1H-indole-6-caboxylic acid methyl ester as an oil.

To a solution of the bromide (500 mg, $1.13 \mathrm{mmol})$ obtained above in DMF $(10 \mathrm{~mL})$ was added $\mathrm{NaH}$ (48.0 mg, $1.20 \mathrm{mmol}, 60 \mathrm{wt} \%$ in mineral oil) with cooling by an ice-water bath and the mixture was stirred for $30 \mathrm{~min}$. $2 \mathrm{~N}$ aqueous $\mathrm{HCl}$ was added to the reaction mixture and the mixture was extracted with EtOAc. The organic layer was washed with water and brine, and dried over $\mathrm{Na}_{2} \mathrm{SO}_{4}$. Filtration and concentration in vacuo and purification by silica gel flash chromatography (n-hexane/EtOAc $=10 / 1 \sim 8 / 1)$ gave $337 \mathrm{mg}(83 \%)$ of $30 \mathrm{a}$ as a solid: ${ }^{1} \mathrm{H}$ NMR $\left(400 \mathrm{MHz}, \mathrm{CDCl}_{3}\right) \delta$ $8.06(\mathrm{~d}, \mathrm{~J}=1.4 \mathrm{~Hz}, 1 \mathrm{H}), 7.88(\mathrm{~d}, \mathrm{~J}=8.3 \mathrm{~Hz}, 1 \mathrm{H}), 7.71(\mathrm{~d}, \mathrm{~J}=8.3 \mathrm{~Hz}, 1 \mathrm{H}), 7.40-7.25(\mathrm{~m}, 4 \mathrm{H}), 4.24$ (t, J = 6.3 Hz, 2H), 3.94 (s, 3H), 3.34 (brt, J = 12.3 Hz, 1H), 3.11 (t, J = 6.3 Hz, 2H), 2.14-2.11 (m, 2H), 1.92-1.87 (m, 5H), 1.50-1.45 (m, 3H); MS (FAB) m/z $360(\mathrm{M}+\mathrm{H})^{+}$.

Step 7: Preparation of 12-Cyclohexyl-5,6-dihydroindolo[2,1-a]isoquinoline-9-carboxylic Acid (6). Compound 30a was converted to 6 by hydrolysis using the procedure described for 7 (step 3 ) in 92\% yield: mp $285-288{ }^{\circ} \mathrm{C} ;{ }^{1} \mathrm{H}$ NMR $\left(300 \mathrm{MHz}\right.$, DMSO-d $\left.{ }_{6}\right) \delta 12.5$ (brs, $\left.1 \mathrm{H}\right), 8.06(\mathrm{~s}, 1 \mathrm{H}), 7.88(\mathrm{~d}$, $\mathrm{J}=8.4 \mathrm{~Hz}, 1 \mathrm{H}), 7.68(\mathrm{~d}, \mathrm{~J}=8.1 \mathrm{~Hz}, 1 \mathrm{H}), 7.59(\mathrm{~d}, \mathrm{~J}=8.4 \mathrm{~Hz}, 1 \mathrm{H}), 7.44-7.42(\mathrm{~m}, 1 \mathrm{H}), 7.33(\mathrm{t}, \mathrm{J}=$ $7.5 \mathrm{~Hz}, 1 \mathrm{H}), 4.27$ (brs, 2H), 3.08 (brs, 2H), 2.57-2.45 (m, 1H), 2.08-2.04 (m, 2H), 1.85-1.76 (m, 5H), 1.46-1.42 (m, 3H); MS (FAB) m/z $346(\mathrm{M}+\mathrm{H})^{+}$. Anal. $\left(\mathrm{C}_{23} \mathrm{H}_{23} \mathrm{NO}_{2}\right) \mathrm{C}, \mathrm{H}, \mathrm{N}$.

\section{2-Cyclohexyl-6,7-dihydro-5-thia-7a-azadibenzo[a,e]azulene-9-carboxylic Acid (11).}

Step 1: Preparation of 2-[2-(2-Bromophenylsulfanyl)ethoxy]tetrahydropyran (33). To a solution of 2-bromobenzenethiol $(3.0 \mathrm{~mL}, 24.9 \mathrm{mmol})$ in DMF $(50.0 \mathrm{~mL})$ was added $\mathrm{NaH}(1.10 \mathrm{~g}$, $27.5 \mathrm{mmol}, 60 \mathrm{wt} \%$ in mineral oil) with cooling by an ice-water bath and the mixture was stirred at the same temperature for $1 \mathrm{~h}$. To the mixture was added 2-(2-bromoethoxy)tetrahydropyran (4.5 $\mathrm{ml}$, $29.7 \mathrm{mmol}$ ) with cooling by an ice-water bath and the mixture was stirred at room temperature for 3 h. Aqueous $\mathrm{Na}_{2} \mathrm{CO}_{3}$ was added to the reaction mixture and the mixture was extracted with EtOAc. The organic layer was washed with water and brine, and dried over $\mathrm{Na}_{2} \mathrm{SO}_{4}$. Filtration and concentration in vacuo and purification by silica gel flash chromatography (n-hexane/EtOAc $=$ 10/1) gave $7.91 \mathrm{~g}$ (quantitative yield) of 33 as a oil: ${ }^{1} \mathrm{H} \mathrm{NMR}\left(400 \mathrm{MHz}, \mathrm{CDCl}_{3}\right) \delta 7.55(\mathrm{dd}, \mathrm{J}=1.2$, 
$8.1 \mathrm{~Hz}, 1 \mathrm{H}), 7.36(\mathrm{dd}, \mathrm{J}=1.6,8.1 \mathrm{~Hz}, 1 \mathrm{H}), 7.29-7.25(\mathrm{~m}, 1 \mathrm{H}), 7.03(\mathrm{dt}, \mathrm{J}=1.4,7.7 \mathrm{~Hz}, 1 \mathrm{H}), 4.65(\mathrm{t}$, $\mathrm{J}=3.5 \mathrm{~Hz}, 1 \mathrm{H}), 4.00-3.94(\mathrm{~m}, 1 \mathrm{H}), 3.91-3.85(\mathrm{~m}, 1 \mathrm{H}), 3.70(\mathrm{td}, \mathrm{J}=5.3,12.8 \mathrm{~Hz}, 1 \mathrm{H}), 3.54-3.49$ (m, 1H), 3.20 (dt, J = 2.0, $6.8 \mathrm{~Hz}, 2 \mathrm{H}), 1.83-1.69(\mathrm{~m}, 2 \mathrm{H}), 1.63-1.50$ (m, 4H).

Steps 2 and 3: Preparation of 3-Cyclohexyl-2-\{2-[2-(tetrahydropyran-2-yloxy)ethylsulfanyl] phenyl\}-1H- indole-6-carboxylic Acid Methyl Ester (28b). To a solution of $21^{2}$ (40.00 g, 119.0 $\mathrm{mmol})$ in 1,4-dioxane $(400 \mathrm{~mL})$ were added pinacolborane $(51.8 \mathrm{~mL}, 357 \mathrm{mmol})$, and then $\mathrm{Et}_{3} \mathrm{~N}$ (66.3 $\mathrm{mL}, 476 \mathrm{mmol}$ ) dropwise at room temperature and the mixture was stirred for $3 \mathrm{~h}$. (2-Biphenyl)dicyclohexylphosphine (5.01 g, $14.3 \mathrm{mmol})$ and $\mathrm{Pd}(\mathrm{OAc})_{2}(802 \mathrm{mg}, 3.57 \mathrm{mmol})$ were added to the mixture and the reaction mixture was heated at $85{ }^{\circ} \mathrm{C}$ for $1.5 \mathrm{~h}$. After cooling, saturated aqueous $\mathrm{NH}_{4} \mathrm{Cl}$ was added to the reaction mixture and the mixture was extracted with EtOAc. The organic layer was washed with water and brine, and dried over $\mathrm{Na}_{2} \mathrm{SO}_{4}$. Filtration and concentration in vacuo gave a solid, which was triturated in n-hexane/EtOAc (20/1) and collected by filtration to give $39.2 \mathrm{~g}(86 \%)$ of 3-cyclohexyl-2-(4,4,5,5-tetramethyl-1,3,2-dioxabororan-2-yl)-1H-indole-6carboxylic acid methyl ester as a solid: ${ }^{1} \mathrm{H}$ NMR $\left(400 \mathrm{MHz}, \mathrm{DMSO}-\mathrm{d}_{6}\right) \delta 11.28(\mathrm{~s}, 1 \mathrm{H}), 8.04(\mathrm{~d}, \mathrm{~J}=$ $1.4 \mathrm{~Hz}, 1 \mathrm{H}), 7.82(\mathrm{~d}, \mathrm{~J}=8.6 \mathrm{~Hz}, 1 \mathrm{H}), 7.53(\mathrm{dd}, \mathrm{J}=1.4,8.6 \mathrm{~Hz}, 1 \mathrm{H}), 3.85(\mathrm{~s}, 3 \mathrm{H}), 2.53-2.48(\mathrm{~m}$, $1 \mathrm{H}), 2.00-1.64(\mathrm{~m}, 7 \mathrm{H}), 1.45-1.27(\mathrm{~m}, 3 \mathrm{H}), 1.35$ (s, 12H).

Compound $28 \mathrm{~b}$ was synthesized from the pinacolborate obtained above and 33 by Suzuki-coupling using the procedure described for $28 \mathrm{a}$ in $87 \%$ yield: ${ }^{1} \mathrm{H} \mathrm{NMR}\left(300 \mathrm{MHz}, \mathrm{CDCl}_{3}\right) \delta 8.86(\mathrm{~s}, 1 \mathrm{H})$, $8.11(\mathrm{~d}, \mathrm{~J}=0.7 \mathrm{~Hz}, 1 \mathrm{H}), 7.82(\mathrm{~d}, \mathrm{~J}=8.4 \mathrm{~Hz}, 1 \mathrm{H}), 7.76(\mathrm{dd}, \mathrm{J}=0.7,8.4 \mathrm{~Hz}, 1 \mathrm{H}), 7.54(\mathrm{~d}, \mathrm{~J}=7.7 \mathrm{~Hz}$ 1H), 7.41-7.25 (m, 3H), $4.50(\mathrm{t}, \mathrm{J}=3.9 \mathrm{~Hz}, 1 \mathrm{H}), 4.12(\mathrm{q}, \mathrm{J}=7.1 \mathrm{~Hz}, 1 \mathrm{H}), 3.93(\mathrm{~s}, 3 \mathrm{H}), 3.84(\mathrm{tt}, \mathrm{J}=$ 4.7, 11.6 Hz, 1H), $3.61(\mathrm{td}, \mathrm{J}=5.3,11.6 \mathrm{~Hz}, 1 \mathrm{H}), 3.44(\mathrm{q}, \mathrm{J}=5.5 \mathrm{~Hz}, 1 \mathrm{H}), 3.05(\mathrm{td}, \mathrm{J}=5.8,5.9 \mathrm{~Hz}$, $1 \mathrm{H}), 2.96(\mathrm{dt}, \mathrm{J}=6.1,6.2 \mathrm{~Hz}, 1 \mathrm{H}), 2.69-2.59(\mathrm{~m}, 1 \mathrm{H}), 1.98-1.69(\mathrm{~m}, 7 \mathrm{H}), 1.68-1.40(\mathrm{~m}, 7 \mathrm{H})$, $1.38-1.22(\mathrm{~m}, 2 \mathrm{H})$.

Step 4: Preparation of 12-Cyclohexyl-6,7-dihydro-5-thia-7a-azadibenzo[a,e]azulene-9carboxylic Acid (11). Compound 11 was synthesized from 28b using the procedure described for 6 (steps 4-7), except mesylate was used instead of bromide as a leaving group in the intramolecular cyclization step: mp 298-300 ${ }^{\circ} \mathrm{C} ;{ }^{1} \mathrm{H}$ NMR $(300 \mathrm{MHz}$, DMSO-d 6 ) $\delta 12.57$ (brs, 1H), 8.18 (d, J = 1.1 $\mathrm{Hz}, 1 \mathrm{H}), 7.89(\mathrm{~d}, \mathrm{~J}=8.4 \mathrm{~Hz}, 1 \mathrm{H}), 7.73-7.70(\mathrm{~m}, 1 \mathrm{H}), 7.65(\mathrm{dd}, \mathrm{J}=1.5,8.4 \mathrm{~Hz}, 1 \mathrm{H}), 7.59$ (d, J = 4.4 $\mathrm{Hz}, 1 \mathrm{H}), 7.49-7.47(\mathrm{~m}, 2 \mathrm{H}), 4.93(\mathrm{dd}, \mathrm{J}=4.8,15.0 \mathrm{~Hz}, 1 \mathrm{H}), 3.80-3.70(\mathrm{~m}, 1 \mathrm{H}), 3.44(\mathrm{dd}, \mathrm{J}=3.7$, $12.1 \mathrm{~Hz}, 1 \mathrm{H}), 3.36-3.28(\mathrm{~m}, 1 \mathrm{H}), 2.76-2.73(\mathrm{~m}, 1 \mathrm{H}), 1.99-1.89$ (m, 4H), 1.78-1.71 (m, 2H), 1.49-1.24 (m, 4H); MS (FAB) m/z $378(\mathrm{M}+\mathrm{H})^{+}$. Anal. (C23H23NO2S) C, H, N. 


\section{2-Cyclohexyl-6,7-dihydro-5-oxa-7a-azadibenzo[a,e]azulene-9-carboxylic Acid (4).}

\section{Step 1: Preparation of 3-Cyclohexyl-2-(2-hydroxyphenyl)-1H-indole-6-carboxylic Acid Methyl}

Ester (29a). Compound $21^{2}$ was converted to 29 a by Suzuki-coupling with 34 using the procedure described for 28a in 88\%yield: ${ }^{1} \mathrm{H}$ NMR $\left(300 \mathrm{MHz}\right.$, DMSO-d $\left.\mathrm{d}_{6}\right) \delta 11.24$ (brs, $\left.1 \mathrm{H}\right), 9.71$ (brs, $\left.1 \mathrm{H}\right)$, $7.98(\mathrm{~d}, \mathrm{~J}=1.5 \mathrm{~Hz}, 1 \mathrm{H}), 7.78(\mathrm{~d}, \mathrm{~J}=8.7 \mathrm{~Hz}, 1 \mathrm{H}), 7.58(\mathrm{dd}, \mathrm{J}=1.5,8.4 \mathrm{~Hz}, 1 \mathrm{H}), 7.20-7.31$ (m, 2H), $7.00(\mathrm{~d}, \mathrm{~J}=7.5 \mathrm{~Hz}, 1 \mathrm{H}), 6.92(\mathrm{t}, \mathrm{J}=7.5 \mathrm{~Hz}, 1 \mathrm{H}), 3.85$ (s, 3H), 2.60-2.75 (m, 1H), 1.62-1.98 (m, $7 \mathrm{H}), 1.14-1.41(\mathrm{~m}, 3 \mathrm{H})$.

Steps 2 and 3: Preparation of 12-Cyclohexyl-6,7-dihydro-5-oxa-7a-azadibenzo[a,e]azulene-9carboxylic Acid Methyl Ester (30c, $\mathrm{n}=2$ ). To a solution of 29a (500 mg, $1.43 \mathrm{mmol}$ ) in acetone $(20 \mathrm{~mL})$ were added $\mathrm{K}_{2} \mathrm{CO}_{3}(237 \mathrm{mg}, 1.72 \mathrm{mmol})$ and 1-bromo-2-chloroethane $(0.14 \mathrm{~mL}, 1.72$ mmol) and the mixture was heated at $50{ }^{\circ} \mathrm{C}$ for $2 \mathrm{~h} . \mathrm{K}_{2} \mathrm{CO}_{3}(474 \mathrm{mg}, 3.44 \mathrm{mmol})$ and 1-bromo-2-chloroethane $(0.28 \mathrm{~mL}, 3.44 \mathrm{mmol})$ were added against the mixture and the mixture was heated at $50{ }^{\circ} \mathrm{C}$ for $24 \mathrm{~h}$. After cooling, water was added to the reaction mixture and the mixture was extracted with EtOAc. The organic layer was washed with brine and dried over $\mathrm{Na}_{2} \mathrm{SO}_{4}$. Filtration and concentration in vacuo and purification by silica gel flash chromatography (n-hexane/EtOAc $=3 / 1)$ gave $370 \mathrm{mg}(63 \%)$ of 2-[2-(2-chloroethoxy)phenyl]-3-cyclohexyl-1Hindole-6-carboxylic acid methyl ester as an oil: ${ }^{1} \mathrm{H}$ NMR $\left(400 \mathrm{MHz}, \mathrm{CDCl}_{3}\right) \delta 9.00(\mathrm{~s}, 1 \mathrm{H})$, 8.06-8.07 (m, 1H), 7.85 (d, J = 8.4 Hz, 1H), 7.74 (ddd, J = 1.2, 8.0, 10.0 Hz, 1H), 7.41 (dd, J = 1.6, $7.6 \mathrm{~Hz}, 1 \mathrm{H}), 7.37$ (dt, J = 1.8, $7.8 \mathrm{~Hz}, 1 \mathrm{H}), 7.12$ (t, J = 7.6 Hz, 1H), 6.99 (d, J = 8.0 Hz, 1H), 4.28 (t, $\mathrm{J}=5.2 \mathrm{~Hz}, 2 \mathrm{H}), 3.93(\mathrm{~s}, 3 \mathrm{H}), 3.81(\mathrm{t}, \mathrm{J}=5.2 \mathrm{~Hz}, 2 \mathrm{H}), 2.88-2.95(\mathrm{~m}, 1 \mathrm{H}), 1.99-2.10(\mathrm{~m}, 2 \mathrm{H})$, $1.76-1.87(\mathrm{~m}, 5 \mathrm{H}), 1.32-1.41$ (m, 3H).

To a solution of 2-[2-(2-chloroethoxy)phenyl]-3-cyclohexyl-1H-indole-6-carboxylic acid methyl ester $(180 \mathrm{mg}, 0.44 \mathrm{mmol})$ in DMF $(6.0 \mathrm{~mL})$ was added $\mathrm{NaH}(20.0 \mathrm{mg}, 0.49 \mathrm{mmol}, 60 \mathrm{wt} \%$ in mineral oil) with cooling by an ice-water bath and the mixture was stirred at room temperature for $24 \mathrm{~h}$. Water was added to the reaction mixture and the mixture was extracted with EtOAc. The organic layer was washed with brine and dried over $\mathrm{Na}_{2} \mathrm{SO}_{4}$. Filtration and concentration in vacuo gave a solid, which was triturated in diisopropylether and collected by filtration to give $70 \mathrm{mg}$ $(42 \%)$ of $30 \mathrm{c}(\mathrm{n}=2)$ as a solid: ${ }^{1} \mathrm{H}$ NMR $\left(400 \mathrm{MHz}, \mathrm{DMSO}_{-} \mathrm{d}_{6}\right) \delta 8.20(\mathrm{~d}, \mathrm{~J}=1.6 \mathrm{~Hz}, 1 \mathrm{H}), 7.89(\mathrm{~d}, \mathrm{~J}$ $=8.4 \mathrm{~Hz}, 1 \mathrm{H}), 7.62(\mathrm{dd}, \mathrm{J}=1.2,8.4 \mathrm{~Hz}, 1 \mathrm{H}), 7.40-7.47(\mathrm{~m}, 2 \mathrm{H}), 7.33(\mathrm{dt}, \mathrm{J}=1.2,7.4 \mathrm{~Hz}, 1 \mathrm{H}), 7.23$ $(\mathrm{dd}, \mathrm{J}=8.0,1.2 \mathrm{~Hz}, 1 \mathrm{H}), 4.33-4.45(\mathrm{~m}, 4 \mathrm{H}), 3.85$ (s, 3H), 2.83-2.90 (m, 1H), 1.95-2.06 (m, 2H), $1.67-1.83(\mathrm{~m}, 5 \mathrm{H}), 1.24-1.44(\mathrm{~m}, 3 \mathrm{H})$; MS (FAB) m/z $376(\mathrm{M}+\mathrm{H})^{+}$.

Step 4: Preparation of 12-Cyclohexyl-6,7-dihydro-5-oxa-7a-azadibenzo[a,e]azulene-9- 
carboxylic Acid (4). Compound 4 was prepared from 30c $(\mathrm{n}=2)$ obtained above using the hydrolysis procedure described for 7 (step 3) in $85 \%$ yield: mp $295-297{ }^{\circ} \mathrm{C} ;{ }^{1} \mathrm{H}$ NMR $(400 \mathrm{MHz}$, DMSO-d $\left._{6}\right) \delta$ 12.54(brs, 1H), $8.17(\mathrm{~s}, 1 \mathrm{H}), 7.86(\mathrm{~d}, \mathrm{~J}=8.4 \mathrm{~Hz}, 1 \mathrm{H}), 7.60(\mathrm{dd}, \mathrm{J}=1.6,8.8 \mathrm{~Hz}, 1 \mathrm{H})$, 7.40-7.47 (m, 2H), 7.33 (dt, J = 0.8, 7.4 Hz, 1H), 7.22 (d, J = 8.0 Hz, 1H), 4.33-4.44 (m, 4H), 2.83-2.91 (m, 1H), 1.95-2.05 (m, 2H), 1.68-1.81 (m, 5H), 1.25-1.37 (m, 3H); MS (FAB) m/z 362 $(\mathrm{M}+\mathrm{H})^{+}$. Anal. $\left(\mathrm{C}_{23} \mathrm{H}_{23} \mathrm{NO}_{3}\right) \mathrm{C}, \mathrm{H}, \mathrm{N}$.

\section{1-Cyclohexyl-5-oxa-6a-azabenzo[a]fluorene-8-carboxylic Acid (8).}

Step 1: Preparation of 11-Cyclohexyl-5-oxa-6a-azabenzo[a]fluorine-8-carboxylic Acid Methyl

Ester $(30 \mathrm{c}, \mathrm{n}=1)$. To a solution of $29 \mathrm{a}(150 \mathrm{mg}, 0.42 \mathrm{mmol})$ in DMF $(7.5 \mathrm{~mL})$ were added $\mathrm{K}_{2} \mathrm{CO}_{3}$ $(1.0 \mathrm{~g}, 7.23 \mathrm{mmol})$ and dibromomethane $(0.15 \mathrm{~mL}, 2.13 \mathrm{mmol})$ and the mixture was heated at $70{ }^{\circ} \mathrm{C}$ for $13 \mathrm{~h}$. After cooling, water was added to the reaction mixture and the mixture was extracted with EtOAc. The organic layer was washed with water and brine, and dried over $\mathrm{Na}_{2} \mathrm{SO}_{4}$. Filtration and concentration in vacuo and purification by silica gel flash chromatography (n-hexane/EtOAc $=10 / 1$ $\sim 5 / 1)$ gave $30 \mathrm{mg}(26 \%)$ of $30 \mathrm{c}(\mathrm{n}=1)$ as a solid: ${ }^{1} \mathrm{H} \mathrm{NMR}\left(400 \mathrm{MHz}, \mathrm{CDCl}_{3}\right) \delta 8.00(\mathrm{~d}, \mathrm{~J}=1.6 \mathrm{~Hz}$, 1H), $7.89(\mathrm{~d}, \mathrm{~J}=8.4 \mathrm{~Hz}, 1 \mathrm{H}), 7.78(\mathrm{dd}, \mathrm{J}=1.6,8.0 \mathrm{~Hz}, 1 \mathrm{H}), 7.75(\mathrm{dd}, \mathrm{J}=1.6,8.8 \mathrm{~Hz}, 1 \mathrm{H}), 7.31$ (td, $\mathrm{J}=0.8,7.6 \mathrm{~Hz}, 1 \mathrm{H}), 7.19(\mathrm{dt}, \mathrm{J}=0.4,7.6 \mathrm{~Hz}, 1 \mathrm{H}), 7.15(\mathrm{dd}, \mathrm{J}=1.2,8.0 \mathrm{~Hz}, 1 \mathrm{H}), 5.86(\mathrm{~s}, 2 \mathrm{H}), 3.95$ (s, 3H), 3.24-3.34 (m, 1H), 2.02-2.15 (m, 2H), 1.81-1.98 (m, 5H), 1.36-1.55 (m, 3H); MS (FAB) $\mathrm{m} / \mathrm{z} 362(\mathrm{M}+\mathrm{H})^{+}$.

Step 2: Preparation of 11-Cyclohexyl-5-oxa-6a-azabenzo[a]fluorene-8-carboxylic Acid (8). Compound 8 was prepared from 30c obtained above using the hydrolysis procedure described for 7 (step 3) in 68\% yield: $\mathrm{mp}>300{ }^{\circ} \mathrm{C} ;{ }^{1} \mathrm{H}$ NMR $(400 \mathrm{MHz}$, DMSO-d 6 ) $\delta 12.65(\mathrm{brs}, 1 \mathrm{H}), 8.19(\mathrm{~d}, \mathrm{~J}=$ $1.2 \mathrm{~Hz}, 1 \mathrm{H}), 7.91(\mathrm{~d}, \mathrm{~J}=8.8 \mathrm{~Hz}, 1 \mathrm{H}), 7.82(\mathrm{dd}, \mathrm{J}=1.6,8.0 \mathrm{~Hz}, 1 \mathrm{H}), 7.63(\mathrm{dd}, \mathrm{J}=1.6,8.8 \mathrm{~Hz}, 1 \mathrm{H})$, $7.37(\mathrm{dt}, \mathrm{J}=1.0,8.4 \mathrm{~Hz}, 1 \mathrm{H}), 7.27$ (dt, J = 0.8, $7.6 \mathrm{~Hz}, 1 \mathrm{H}), 7.21$ (dd, J = 1.2, 8.0 Hz, 1H), 6.07 (s, 2H), 3.21-3.35 (m, 1H), 1.99-2.13 (m, 2H), 1.72-1.91 (m, 5H), 1.37-1.55 (m, 3H); MS (FAB) m/z $348(\mathrm{M}+\mathrm{H})^{+}$. Anal. $\left(\mathrm{C}_{22} \mathrm{H}_{21} \mathrm{NO}_{3}\right) \mathrm{C}, \mathrm{H}, \mathrm{N}$.

\section{4-Cyclohexyl-7,8-dihydro-6H-indole[1,2e][1,5]benzoxazocine-11-carboxylic Acid (9).}

Compound 9 was prepared from 29a using the procedure described above for 4, except 1-bromo-3-chloropropane was used instead of 1-bromo-2-chloroethane in step 2: mp $285-286{ }^{\circ} \mathrm{C}$; ${ }^{1} \mathrm{H}$ NMR (300MHz, DMSO-d $\left.{ }_{6}\right) \delta 12.52$ (brs, 1H), 8.10 (s, 1H), 7.85 (d, J = 8.4 Hz, 1H), 7.65 (d, J = $8.4 \mathrm{~Hz}, 1 \mathrm{H}), 7.50$ (t, J = 7.5 Hz, 1H), 7.33-7.20 (m, 3H), 4.62 (brd, J = $15.8 \mathrm{~Hz}, 1 \mathrm{H}), 4.30$ (td, J = 
4.0, $12.5 \mathrm{~Hz}, 1 \mathrm{H}), 3.98(\mathrm{dt}, \mathrm{J}=3.5,12.0 \mathrm{~Hz}, 1 \mathrm{H}), 3.63(\mathrm{dd}, \mathrm{J}=8.5,15.8 \mathrm{~Hz}, 1 \mathrm{H}), 2.75-2.60(\mathrm{~m}$, 1H), 2.05-1.80 (m, 6H), 1.78-1.62 (m, 2H), 1.59-1.47 (m, 1H), 1.40-1.15 (m, 3H); MS (FAB) m/z $376(\mathrm{M}+\mathrm{H})^{+}$. Anal. $\left(\mathrm{C}_{24} \mathrm{H}_{25} \mathrm{NO}_{3}\right) \mathrm{C}, \mathrm{H}, \mathrm{N}$.

13-Cyclohexyl-6,7-dihydro-5H-benzo[5,6][1,4]diazepino[7,1-a]indole-10-carboxylic Acid Hydrochloride (10).

Step 1: Preparation of 2-(4,4,5,5-Tetramethyl[1,3,2]dioxabororan-2-yl)phenylamine (35). To a solution of 2-bromoaniline $(1.0 \mathrm{~g}, 5.81 \mathrm{mmol})$ in 1,4-dioxane $(15 \mathrm{~mL})$ were added $\mathrm{Et}_{3} \mathrm{~N}(3.24 \mathrm{~mL}$, $23.2 \mathrm{mmol})$ and $\mathrm{PdCl}_{2}(\mathrm{dppf}) \cdot \mathrm{CH}_{2} \mathrm{Cl}_{2}(243 \mathrm{mg}, 0.30 \mathrm{mmol})$. Pinacolborane (2.53 ml, $\left.17.4 \mathrm{mmol}\right)$ was added to the mixture dropwise and the reaction mixture was heated at $100{ }^{\circ} \mathrm{C}$ for $3 \mathrm{~h}$. After the reaction mixture was cooled, saturated aqueous $\mathrm{NH}_{4} \mathrm{Cl}$ was added to the reaction mixture and the mixture was extracted with EtOAc. The organic layer was washed with brine and dried over $\mathrm{Na}_{2} \mathrm{SO}_{4}$. Filtration and concentration in vacuo and purification by silica gel flash chromatography (n-hexane/EtOAc $=5 / 1)$ gave $810 \mathrm{mg}(64 \%)$ of 35 as a solid; ${ }^{1} \mathrm{H}$ NMR $\left(400 \mathrm{MHz}, \mathrm{CDCl}_{3}\right) \delta 7.59$ $(\mathrm{dd}, \mathrm{J}=1.6,7.2 \mathrm{~Hz}, 1 \mathrm{H}), 7.20(\mathrm{ddd}, \mathrm{J}=2.0,7.2,15.2 \mathrm{~Hz}, 1 \mathrm{H}), 6.66(\mathrm{t}, \mathrm{J}=7.4 \mathrm{~Hz}, 1 \mathrm{H}), 6.58(\mathrm{~d}, \mathrm{~J}=$ $8.0 \mathrm{~Hz}, 1 \mathrm{H}), 4.72$ (brs, 2H), 1.33 (s, 12H).

Step 2: Preparation of 2-(2-Aminophenyl)-3-cyclohexyl-1H-indole-6-carboxylic Acid Methyl Ester (29b). Compound $21^{2}$ was converted to $29 \mathrm{~b}$ by Suzuki-coupling with 35 using the procedure described for 28a in 96\%yield: ${ }^{1} \mathrm{H}$ NMR $\left(400 \mathrm{MHz}, \mathrm{DMSO}_{-} \mathrm{d}_{6}\right) \delta 11.30(\mathrm{~s}, 1 \mathrm{H}), 7.95(\mathrm{~d}, \mathrm{~J}=1.2 \mathrm{~Hz}$, 1H), $7.78(\mathrm{~d}, \mathrm{~J}=8.4 \mathrm{~Hz}, 1 \mathrm{H}), 7.58(\mathrm{dd}, \mathrm{J}=1.2,8.4 \mathrm{~Hz}, 1 \mathrm{H}), 7.14(\mathrm{dt}, \mathrm{J}=0.8,8.0 \mathrm{~Hz}, 1 \mathrm{H}), 7.04$ (dd, $\mathrm{J}=1.6,7.6 \mathrm{~Hz}, 1 \mathrm{H}), 6.79(\mathrm{dd}, \mathrm{J}=0.8,8.0 \mathrm{~Hz}, 1 \mathrm{H}), 6.65(\mathrm{dt}, \mathrm{J}=0.4,7.2 \mathrm{~Hz}, 1 \mathrm{H}), 4.81$ (brs, 2H), $3.84(\mathrm{~s}, 3 \mathrm{H}), 2.53-2.63(\mathrm{~m}, 1 \mathrm{H}), 1.63-1.94(\mathrm{~m}, 7 \mathrm{H}), 1.16-1.37(\mathrm{~m}, 3 \mathrm{H})$.

Steps 3-5: Preparation of 13-Cyclohexyl-6,7-dihydro-5H-benzo[5,6][1,4]diazepino[7,1-a] indole-10-carboxylic Acid Methyl Ester (30d). To a suspension of 29b (6.48 g, $18.6 \mathrm{mmol}$ ) and AcONa (1.68 g, $20.5 \mathrm{mmol})$ in $\mathrm{AcOH}(1.17 \mathrm{~mL}, 20.5 \mathrm{mmol})$ and THF $(60 \mathrm{~mL})$ was added chloroacetyl chloride $(1.63 \mathrm{~mL}, 20.5 \mathrm{mmol})$ dropwise and the mixture was stirred at room temperature for $2 \mathrm{~h}$. Saturated aqueous $\mathrm{NaHCO}_{3}$ was added to the reaction mixture and the mixture was extracted with EtOAc. The organic layer was washed with saturated aqueous $\mathrm{NaHCO}_{3}$ and brine, and dried over $\mathrm{MgSO}_{4}$. Filtration and concentration in vacuo gave $7.90 \mathrm{~g}(100 \%)$ of 2-[2-(2-chloroacetylamino)phenyl]-3-cyclohexyl-1H-indole-6-caboxylic acid methyl ester as a solid: ${ }^{1} \mathrm{H}$ NMR (400MHz, DMSO-d 6 ) $\delta 11.44$ (s, 1H), $9.38(\mathrm{~s}, 1 \mathrm{H}), 7.98$ (d, J = 1.2 Hz, 1H), 7.90 (d, $\mathrm{J}=8.0 \mathrm{~Hz}, 1 \mathrm{H}), 7.82(\mathrm{~d}, \mathrm{~J}=8.4 \mathrm{~Hz}, 1 \mathrm{H}), 7.60(\mathrm{dd}, \mathrm{J}=1.2,8.0 \mathrm{~Hz}, 1 \mathrm{H}), 7.47(\mathrm{dt}, \mathrm{J}=0.8,8.4 \mathrm{~Hz}$, 
1H), $7.36(\mathrm{dd}, \mathrm{J}=1.6,7.6 \mathrm{~Hz}, 1 \mathrm{H}), 7.30(\mathrm{dt}, \mathrm{J}=0.6,7.6 \mathrm{~Hz}, 1 \mathrm{H}), 4.19(\mathrm{~s}, 2 \mathrm{H}), 3.85(\mathrm{~s}, 3 \mathrm{H})$, 2.42-2.50 (m, 1H), 1.61-1.91 (m, 7H), 1.11-1.34 (m, 3H).

To a solution of the chloroacetylanilide $(7.90 \mathrm{~g}, 18.6 \mathrm{mmol})$ obtained above in DMF $(170 \mathrm{~mL})$ was added $\mathrm{NaH}$ (1.67 g, $40.9 \mathrm{mmol}, 60 \mathrm{wt} \%$ in mineral oil) with cooling by an ice-water bath and the mixture was stirred at room temperature for $2 \mathrm{~h}$. To the reaction mixture was added water and the precipitates were collected by filtration to give $6.72 \mathrm{~g}$ (93\%) of 13-cyclohexyl-6-oxo-6,7-dihydro5H-benzo[5,6][1,4]diazepino[7,1-a]indole-10-carboxylic acid methyl ester as a solid: ${ }^{1} \mathrm{H}$ NMR $\left(400 \mathrm{MHz}, \mathrm{DMSO}_{-} \mathrm{d}_{6}\right) \delta 10.34(\mathrm{~s}, 1 \mathrm{H}), 8.27(\mathrm{~d}, \mathrm{~J}=1.2 \mathrm{~Hz}, 1 \mathrm{H}), 7.96(\mathrm{~d}, \mathrm{~J}=8.4 \mathrm{~Hz}, 1 \mathrm{H}), 7.68(\mathrm{dd}, \mathrm{J}$ $=1.6,8.4 \mathrm{~Hz}, 1 \mathrm{H}), 7.49-7.53(\mathrm{~m}, 2 \mathrm{H}), 7.38(\mathrm{t}, \mathrm{J}=7.6 \mathrm{~Hz}, 1 \mathrm{H}), 7.28(\mathrm{~d}, \mathrm{~J}=8.0 \mathrm{~Hz}, 1 \mathrm{H}), 5.07(\mathrm{~d}, \mathrm{~J}$ $=15.6 \mathrm{~Hz}, 1 \mathrm{H}), 4.52(\mathrm{~d}, \mathrm{~J}=14.8 \mathrm{~Hz}, 1 \mathrm{H}), 3.89(\mathrm{~s}, 3 \mathrm{H}), 2.81-2.91(\mathrm{~m}, 1 \mathrm{H}), 1.98-2.11(\mathrm{~m}, 3 \mathrm{H})$, $1.84-1.94(\mathrm{~m}, 1 \mathrm{H}), 1.66-1.78(\mathrm{~m}, 2 \mathrm{H}), 1.34-1.56(\mathrm{~m}, 3 \mathrm{H}), 1.10-1.27(\mathrm{~m}, 1 \mathrm{H})$.

To a suspension of the lactam $(6.72 \mathrm{~g}, 17.3 \mathrm{mmol})$ obtained above in THF $(13 \mathrm{~mL})$ was added $1 \mathrm{M}$ $\mathrm{BH}_{3} \cdot$ THF complex THF solution $(67 \mathrm{~mL})$ with cooling by an ice-water bath and the mixture was stirred at room temperature for $4 \mathrm{~h}$. To the reaction mixture was added $2 \mathrm{~N}$ aqueous $\mathrm{HCl}(40 \mathrm{~mL})$ and the mixture was heated at $70{ }^{\circ} \mathrm{C}$ for $1 \mathrm{~h}$. After cooling, $2 \mathrm{~N}$ aqueous $\mathrm{NaOH}(40 \mathrm{~mL})$ was added to the mixture and the mixture was extracted with EtOAc. The organic layer was washed with saturated aqueous $\mathrm{NaHCO}_{3}$ and brine, and dried over $\mathrm{MgSO}_{4}$. Filtration and concentration in vacuo gave $6.08 \mathrm{~g}(94 \%)$ of $30 \mathrm{~d}$ as a solid: ${ }^{1} \mathrm{H}$ NMR $\left(400 \mathrm{MHz}, \mathrm{DMSO}-\mathrm{d}_{6}\right) \delta 8.13(\mathrm{~d}, \mathrm{~J}=1.6 \mathrm{~Hz}, 1 \mathrm{H}), 7.86$ $(\mathrm{d}, \mathrm{J}=8.8 \mathrm{~Hz}, 1 \mathrm{H}), 7.61(\mathrm{dd}, \mathrm{J}=1.6,8.8 \mathrm{~Hz}, 1 \mathrm{H}), 7.17-7.21(\mathrm{~m}, 2 \mathrm{H}), 6.91(\mathrm{dd}, \mathrm{J}=1.2,8.4 \mathrm{~Hz}, 1 \mathrm{H})$, 6.83 (t, J = 7.4 Hz, 1H), 5.80 (t, J = 4.0 Hz, 1H), 4.41 (brs, 2H), 3.86 (s, 3H), 3.45-3.52 (m, 2H), 2.80-2.89 (m, 1H), 1.97-2.10 (m, 2H), 1.68-1.85 (m, 5H), 1.21-1.46 (m, 3H).

\section{Step 6: Preparation of 13-Cyclohexyl-6,7-dihydro-5H-benzo[5,6][1,4]diazepino[7,1-a]indole-} 10-carboxylic Acid Hydrochloride (10). To a solution of $30 \mathrm{~d}$ (60.0 mg, $0.16 \mathrm{mmol})$ in $\mathrm{MeOH}(1.0$ $\mathrm{mL})$ and THF $(1.0 \mathrm{~mL})$ was added $4 \mathrm{~N}$ aqueous $\mathrm{NaOH}(1.0 \mathrm{~mL})$ and the mixture was stirred at room temperature for $36 \mathrm{~h}$. The reaction mixture was neutralized to $\mathrm{pH} 7$ with $1 \mathrm{~N}$ aqueous $\mathrm{HCl}(4.0 \mathrm{~mL})$ and the mixture was extracted with EtOAc. The organic layer was washed with brine and dried over $\mathrm{MgSO}_{4}$. After filtrating, the solvent was removed by evaporation in vacuo and the residue was dissolved in THF. To the solution was added $4 \mathrm{~N} \mathrm{HCl}$ in EtOAc $(1.0 \mathrm{~mL})$. Concentration in vacuo gave a solid, which was triturated in diethyl ether and collected by filtration to give $48.0 \mathrm{mg}$ (76\%) of 10 as a solid: $\mathrm{mp} 271-275{ }^{\circ} \mathrm{C} ;{ }^{1} \mathrm{H}$ NMR $\left(300 \mathrm{MHz}, \mathrm{DMSO}-\mathrm{d}_{6}\right) \delta 8.18(\mathrm{~s}, 1 \mathrm{H}), 7.89(\mathrm{~d}, \mathrm{~J}=8.4 \mathrm{~Hz}$, 1H), $7.65(\mathrm{~d}, \mathrm{~J}=9.9 \mathrm{~Hz}, 1 \mathrm{H}), 7.18-7.44(\mathrm{~m}, 4 \mathrm{H}), 3.46-4.47$ (m, 4H), 2.81-2.91 (m, 1H), 1.96-2.11 $(\mathrm{m}, 2 \mathrm{H}), 1.68-1.86(\mathrm{~m}, 5 \mathrm{H}), 1.22-1.45(\mathrm{~m}, 3 \mathrm{H}) ; \mathrm{MS}(\mathrm{FAB}) \mathrm{m} / \mathrm{z} 361(\mathrm{M}+\mathrm{H})^{+}$. Anal. 
$\left(\mathrm{C}_{23} \mathrm{H}_{24} \mathrm{~N}_{2} \mathrm{O}_{2} \cdot \mathrm{HCl}\right) \mathrm{C}, \mathrm{H}, \mathrm{N}$.

\section{3-Cyclohexyl-5-Methyl-6,7-dihydro-5H-benzo[5,6][1,4]diazepino[7,1-a]indole-10-carboxylic} Acid (13).

To a solution of $30 \mathrm{~d}(60.0 \mathrm{mg}, 0.16 \mathrm{mmol})$ in $\mathrm{CHCl}_{3}(1.5 \mathrm{~mL})$ and $37 \%$ aqueous $\mathrm{HCHO}(0.2 \mathrm{~mL})$ was added $\mathrm{NaBH}(\mathrm{OAc})_{3}(51.0 \mathrm{mg}, 0.24 \mathrm{mmol})$ and the mixture was stirred at room temperature for $24 \mathrm{~h}$. The reaction mixture was poured into water and extracted with EtOAc. The organic layer was washed with brine, dried over $\mathrm{MgSO}_{4}$. Filtration and concentration in vacuo gave 13-cyclohexyl-5-methyl -6,7-dihydro-5H-benzo[5,6][1,4]diazepino[7,1-a]indole-10 carboxylic acid methyl ester $31 \mathrm{a}$ as a crude oil.

The crude 31a obtained above was converted to compound 13 by using the hydrolysis procedure described for 7 (step 3) in 75\% yield from 30d: mp 288-289 ${ }^{\circ} \mathrm{C} ;{ }^{1} \mathrm{H}$ NMR $\left(400 \mathrm{MHz}, \mathrm{DMSO}-\mathrm{d}_{6}\right) \delta$ $12.51(\mathrm{~s}, 1 \mathrm{H}), 8.15(\mathrm{~d}, \mathrm{~J}=1.2 \mathrm{~Hz}, 1 \mathrm{H}), 7.84(\mathrm{~d}, \mathrm{~J}=8.6 \mathrm{~Hz}, 1 \mathrm{H}), 7.60(\mathrm{dd}, \mathrm{J}=1.2,8.6 \mathrm{~Hz}, 1 \mathrm{H}), 7.43$ $(\mathrm{dt}, \mathrm{J}=1.6,7.8 \mathrm{~Hz}, 1 \mathrm{H}), 7.28(\mathrm{dd}, \mathrm{J}=1.4,7.8 \mathrm{~Hz}, 1 \mathrm{H}), 7.17(\mathrm{~d}, \mathrm{~J}=7.8 \mathrm{~Hz}, 2 \mathrm{H}), 7.15$ (t, J = 7.6 Hz, 2H), 4.90-4.25 (m, 1H), 3.95-3.00 (m, 3H), 2.79 (brt, J = 12.0 Hz, 1H), $2.73(\mathrm{~s}, 3 \mathrm{H}), 2.08-1.95(\mathrm{~m}$, 2H), 1.88-1.65 (m, 4H), 1.45-1.20 (m, 4H); MS (FAB) m/z $375(\mathrm{M}+\mathrm{H})^{+}$; HPLC method A, 97\% (16.0 min); HPLC method B, 95\% (2.42 min).

\section{5-Acetyl- 13-Cyclohexyl -6,7-dihydro-5H-benzo[5,6][1,4]diazepino[7,1-a]indole-10-carboxylic} Acid (15).

To a solution of $30 \mathrm{~d}(60.0 \mathrm{mg}, 0.16 \mathrm{mmol})$ in pyridine $(1.0 \mathrm{~mL})$ was added $\mathrm{Ac}_{2} \mathrm{O}(0.023 \mathrm{~mL}, 0.24$ $\mathrm{mmol}$ ) and the mixture was stirred at room temperature for $24 \mathrm{~h}$. The reaction mixture was added water and the precipitates were collected by filtration to give $31 \mathrm{~b}$ as a crude solid.

The crude $31 \mathrm{~b}$ obtained above was converted to compound 15 by using the hydrolysis procedure described for 7 (step 3) in 77\% yield from $30 \mathrm{~d}$ : $\mathrm{mp}>300{ }^{\circ} \mathrm{C} ;{ }^{1} \mathrm{H}$ NMR $\left(300 \mathrm{MHz}, \mathrm{DMSO}-\mathrm{d}_{6}\right) \delta 12.5$ (brs, 1H), 8.20 (s, 1H), 7.87 (d, J = 8.4 Hz, 1H), 7.69-7.53 (m, 5H), 4.90-4.75 (m, 2H), 3.75-3.55 (m, 1H), 3.40-3.30 (m, 1H), $2.90(\mathrm{t}, \mathrm{J}=11.0 \mathrm{~Hz}, 1 \mathrm{H}), 2.10-1.83(\mathrm{~m}, 4 \mathrm{H}), 1.80-1.68(\mathrm{~m}, 3 \mathrm{H})$, 1.55-1.30 (m, 3H), $1.50(\mathrm{~s}, 3 \mathrm{H})$; MS (FAB) m/z $403(\mathrm{M}+\mathrm{H})^{+}$. Anal. $\left(\mathrm{C}_{25} \mathrm{H}_{26} \mathrm{~N}_{2} \mathrm{O}_{3}\right) \mathrm{C}, \mathrm{H}, \mathrm{N}$.

13-Cyclohexyl-5-(2-piperidin-1-ylethyl)-6,7-dihydro-5H-benzo[5,6][1,4]diazepino[7,1-a]indole10-carboxylic Acid Dihydrochloride (20).

Steps 1-4: Preparation of 13-Cyclohexyl-5-(2-piperidin-1-ylethyl)-6,7-dihydro-5H-benzo 
[5,6][1,4]diazepino[7,1-a]indole-10-carboxylic Acid Methyl Ester (31d, R = 2-piperidin-1-yl ethyl). To a solution of $30 \mathrm{~d}(2.00 \mathrm{~g}, 5.34 \mathrm{mmol})$ in DMF $(16 \mathrm{~mL})$ were added $\mathrm{K}_{2} \mathrm{CO}_{3}(1.85 \mathrm{~g}, 13.4$ $\mathrm{mmol}), \mathrm{NaI}(800 \mathrm{mg}, 5.34 \mathrm{mmol})$ and bromoacetic acid tert-butyl ester $(1.18 \mathrm{~mL}, 8.01 \mathrm{mmol})$ and the mixture was heated at $90{ }^{\circ} \mathrm{C}$ for $12 \mathrm{~h}$. After cooling, the reaction mixture was poured into water and the precipitates were collected by filtration to give $2.47 \mathrm{~g}$ (95\%) of 5-tert-butoxycarbonyl methyl-13-cyclohexyl-6,7-dihydro-5H-benzo[5,6][1,4]diazepino[7,1-a]indole-10-carboxylic acid methyl ester as a solid: ${ }^{1} \mathrm{H}$ NMR $\left(400 \mathrm{MHz}, \mathrm{DMSO}_{6}\right) \delta 8.18(\mathrm{~d}, \mathrm{~J}=1.2 \mathrm{~Hz}, 1 \mathrm{H}), 7.88(\mathrm{~d}, \mathrm{~J}=8.8$ $\mathrm{Hz}, 1 \mathrm{H}), 7.62(\mathrm{dd}, \mathrm{J}=1.2,8.0 \mathrm{~Hz}, 1 \mathrm{H}), 7.38(\mathrm{t}, \mathrm{J}=7.8 \mathrm{~Hz}, 1 \mathrm{H}), 7.28(\mathrm{~d}, \mathrm{~J}=7.6 \mathrm{~Hz}, 1 \mathrm{H}), 7.14$ (t, J = $7.4 \mathrm{~Hz}, 1 \mathrm{H}), 7.02$ (d, J = 8.0 Hz, 1H), 3.87 (s, 5H), 3.51 (brs, 2H), 2.75-2.85 (m, 1H), 1.95-2.09 (m, 2H), 1.66-1.86 (m, 5H), 1.17-1.45 (m, 3H), 1.29 (s, 9H); MS (FAB) m/z $489(\mathrm{M}+\mathrm{H})^{+}$.

To a solution of the tert-butyl ester $(2.47 \mathrm{~g}, 5.05 \mathrm{mmol})$ obtained above in $\mathrm{CHCl}_{3}(17 \mathrm{~mL})$ was added trifluoroacetic acid $(17 \mathrm{~mL})$ and the mixture was stirred at room temperature for $5 \mathrm{~h}$. The solvent was removed by evaporation in vacuo and the residue was purified by silica gel flash chromatography $\left(\mathrm{CHCl}_{3} / \mathrm{MeOH}=30 / 1 \sim 15 / 1\right)$ gave $1.34 \mathrm{~g}$ (61\%) of 13-cyclohexyl-10methoxycarbonyl-6,7-dihydro-5H-benzo[5,6][1,4]diazepino[7,1-a]indole-5-yl) acetic acid as a solid: ${ }^{1} \mathrm{H}$ NMR (400MHz, DMSO-d $\left.{ }_{6}\right) \delta 12.60$ (brs, $\left.1 \mathrm{H}\right), 8.18$ (d, J = $\left.1.2 \mathrm{~Hz}, 1 \mathrm{H}\right), 7.87$ (d, J = 8.4 $\mathrm{Hz}, 1 \mathrm{H}), 7.62(\mathrm{dd}, \mathrm{J}=1.6,8.8 \mathrm{~Hz}, 1 \mathrm{H}), 7.37$ (dt, J = 0.8, 8.0 Hz, 1H), 7.27 (dd, J = 1.6, 7.6 Hz, 1H), $7.11(\mathrm{t}, \mathrm{J}=7.4 \mathrm{~Hz}, 1 \mathrm{H}), 7.05$ (d, J = 8.0 Hz, 1H), 4.40 (brs, 2H), 3.88 (brs, 2H), 3.87 (s, 3H), 3.58 (t, $\mathrm{J}=5.4 \mathrm{~Hz}, 2 \mathrm{H}), 2.76-2.86(\mathrm{~m}, 1 \mathrm{H}), 1.94-2.07(\mathrm{~m}, 2 \mathrm{H}), 1.66-1.86(\mathrm{~m}, 5 \mathrm{H}), 1.20-1.45(\mathrm{~m}, 3 \mathrm{H})$; MS (FAB) $\mathrm{m} / \mathrm{z} 433(\mathrm{M}+\mathrm{H})^{+}$.

To a solution of the carboxylic acid (200 $\mathrm{mg}, 0.46 \mathrm{mmol})$ obtained above, 1-ethyl-3-(3'-dimethylaminopropyl)carbodiimide hydrochloride $(106 \mathrm{mg}, 0.55 \mathrm{mmol})$ and 1-hydroxybenzotriazole hydrate $(75 \mathrm{mg}, 0.55 \mathrm{mmol})$ in DMF $(2.0 \mathrm{~mL})$ was added piperidine $(0.13$ $\mathrm{mL}, 1.39 \mathrm{mmol}$ ) and the mixture was stirred at room temperature for $4 \mathrm{~h}$. The reaction mixture was poured into water and extracted with EtOAc. The organic layer was washed with brine and dried over $\mathrm{MgSO}_{4}$. Filtration and concentration in vacuo and purification by silica gel flash chromatography (n-hexane/EtOAc $=1 / 1 \sim 1 / 2$ ) gave $181 \mathrm{mg}$ (78\%) of 13-cyclohexyl-5-[2-oxo-2(piperidin-1-yl)ethyl]-6,7-dihydro-5H-benzo[5,6][1,4]diazepino[7,1-a]indole-10-carboxylic acid methyl ester as a solid: ${ }^{1} \mathrm{H}$ NMR $\left(400 \mathrm{MHz}, \mathrm{DMSO}_{-} \mathrm{d}_{6}\right) \delta 8.19(\mathrm{~d}, \mathrm{~J}=1.2 \mathrm{~Hz}, 1 \mathrm{H}), 7.87(\mathrm{~d}, \mathrm{~J}=8.3$ $\mathrm{Hz}, 1 \mathrm{H}), 7.61(\mathrm{dd}, \mathrm{J}=1.5,8.5 \mathrm{~Hz}, 1.0 \mathrm{H}), 7.39(\mathrm{dt}, \mathrm{J}=1.5,7.7 \mathrm{~Hz}, 1 \mathrm{H}), 7.29$ (dd, J = 1.6, $7.7 \mathrm{~Hz}$, 1H), $7.15(\mathrm{t}, \mathrm{J}=7.4 \mathrm{~Hz}, 1 \mathrm{H}), 7.09(\mathrm{~d}, \mathrm{~J}=8.1 \mathrm{~Hz}, 1 \mathrm{H}), 5.00-4.30(\mathrm{~m}, 2 \mathrm{H}), 3.94$ (brs, 2.0H), 3.86 (s, $3 \mathrm{H}), 3.45$ (brs, 2H), 3.35-3.25 (m, 2H), 3.08 (brs, 2H), 2.81 (tt, J = 3.2, $12.0 \mathrm{~Hz}, 1 \mathrm{H}), 2.10-1.95(\mathrm{~m}$, 
2H), 1.90-1.60 (m, 5H), 1.45-1.15 (m, 7H), 1.05-0.80 (m, 2H).

To a solution of the amide $(120 \mathrm{mg}, 0.24 \mathrm{mmol})$ obtained above in THF $(1.0 \mathrm{~mL})$ was added $1 \mathrm{M}$ $\mathrm{BH}_{3} \cdot$ THF complex THF solution $(1.2 \mathrm{~mL})$ with cooling by an ice-water bath and the mixture was stirred at room temperature for $13 \mathrm{~h}$. To the reaction mixture was added $2 \mathrm{~N}$ aqueous $\mathrm{HCl}(3.0 \mathrm{~mL})$ and the mixture was heated at $60{ }^{\circ} \mathrm{C}$ for $7 \mathrm{~h}$. After cooling, the mixture was made basic by $2 \mathrm{~N}$ aqueous $\mathrm{NaOH}(5.5 \mathrm{ml})$ and the precipitates were collected by filtration to give $111 \mathrm{mg}(95 \%)$ of 31d ( $\mathrm{R}=2$-piperidin-1-ylethyl) as a solid: ${ }^{1} \mathrm{H}$ NMR (400MHz, DMSO-d $\left.{ }_{6}\right) \delta 8.17(\mathrm{~d}, \mathrm{~J}=1.2 \mathrm{~Hz}, 1 \mathrm{H})$, $7.86(\mathrm{~d}, \mathrm{~J}=8.3 \mathrm{~Hz}, 1 \mathrm{H}), 7.61(\mathrm{dd}, \mathrm{J}=1.4,8.6 \mathrm{~Hz}, 1 \mathrm{H}), 7.43(\mathrm{dt}, \mathrm{J}=1.4,7.7 \mathrm{~Hz}, 1 \mathrm{H}), 7.29(\mathrm{dd}, \mathrm{J}=$ 7.4, 1.6 Hz, 1H), $7.25(\mathrm{~d}, \mathrm{~J}=7.7 \mathrm{~Hz}, 1 \mathrm{H}), 7.16(\mathrm{t}, \mathrm{J}=7.4 \mathrm{~Hz}, 1 \mathrm{H}), 3.87(\mathrm{~s}, 3 \mathrm{H}), 4.75-4.00$ (m, 2H), 3.50-3.00 (m, 4H), $2.82(\mathrm{tt}, \mathrm{J}=2.8,12.0 \mathrm{~Hz}, 1 \mathrm{H}), 2.27(\mathrm{t}, \mathrm{J}=6.8 \mathrm{~Hz}, 2 \mathrm{H}), 2.20-2.15(\mathrm{~m}, 4 \mathrm{H})$, 2.05-1.95 (m, 2H), 1.85-1.65 (m, 4H), 1.40-1.20 (m, 10H).

Step 5: Preparation of 13-Cyclohexyl-5-(2-piperidin-1-ylethyl)-6,7-dihydro-5H-benzo[5,6][1,4] diazepino[7,1-a]indole-10-carboxylic Acid Dihydrochloride (20). The ester 31d ( $\mathrm{R}=$ 2-piperidin-1-ylethyl) obtained above was hydrolyzed to give compound 20 by using the hydrolysis procedure described for 10 (step 6) in 72\% yield: mp 196-200 ${ }^{\circ} \mathrm{C} ;{ }^{1} \mathrm{H}$ NMR $\left(400 \mathrm{MHz}, \mathrm{DMSO}-\mathrm{d}_{6}\right) \delta$ 12.54 (brs, 1H), 9.55 (brs, 1H), 8.17 (d, J = 1.2 Hz, 1H), 7.85 (d, J = 8.6 Hz, 1H), 7.60 (dd, J = 1.3, $8.5 \mathrm{~Hz}, 1 \mathrm{H}), 7.50$ (dt, J = 1.6, 7.7 Hz, 1H), 7.37 (dd, J = 1.5, $7.7 \mathrm{~Hz}, 1 \mathrm{H}), 7.32$ (d, J = 7.7 Hz, 1H), 7.28 (t, J = 7.4 Hz, 1H), 4.75 (brs, 1H), 3.91-3.53 (m, 5H), 3.50-3.30 (m, 1H), 3.20-2.90 (m, 5H), 2.84 (brt, J = 12.2 Hz, 1H), 2.65-2.50 (m, 1H), 2.10-1.95 (m, 2H), 1.90-1.65 (m, 4H), 1.50-1.20 $(\mathrm{m}, 9 \mathrm{H}), 1.10-0.95(\mathrm{~m}, 1 \mathrm{H}) ;{ }^{1} \mathrm{H}$ NMR $\left(300 \mathrm{MHz}, \mathrm{DMSO}_{6}, 90{ }^{\circ} \mathrm{C}\right) \delta 10.02(\mathrm{~s}, 1 \mathrm{H}), 8.12(\mathrm{~d}, \mathrm{~J}=1.1$ $\mathrm{Hz}, 1 \mathrm{H}), 7.82(\mathrm{~d}, \mathrm{~J}=8.4 \mathrm{~Hz}, 1 \mathrm{H}), 7.61(\mathrm{dd}, \mathrm{J}=1.5,8.4 \mathrm{~Hz}, 1 \mathrm{H}), 7.48(\mathrm{dt}, \mathrm{J}=1.4,7.7 \mathrm{~Hz}, 1 \mathrm{H}), 7.39$ $(\mathrm{dd}, \mathrm{J}=1.5,7.5 \mathrm{~Hz}, 1 \mathrm{H}), 7.31(\mathrm{dd}, \mathrm{J}=0.9,8.2 \mathrm{~Hz}, 1 \mathrm{H}), 7.25(\mathrm{dt}, \mathrm{J}=1.1,7.5 \mathrm{~Hz}, 1 \mathrm{H}), 4.22$ (brs, $2 \mathrm{H}), 3.58$ (t, J = 6.0 Hz, 2H), 3.43 (brs, 2H), 3.15-2.95 (m, 3H), 3.02 (brs, 2H), 2.88 (tt, J = 3.2, $12.2 \mathrm{~Hz}, 1 \mathrm{H}), 2.65-2.50(\mathrm{~m}, 1 \mathrm{H}), 2.05-1.90(\mathrm{~m}, 2 \mathrm{H}), 1.85-1.70(\mathrm{~m}, 5 \mathrm{H}), 1.60-1.20(\mathrm{~m}, 9 \mathrm{H})$, 1.15-1.00 (m, 1H); MS (FAB) m/z $433(\mathrm{M}+\mathrm{H})^{+}$. Anal. $\left(\mathrm{C}_{30} \mathrm{H}_{37} \mathrm{~N}_{3} \mathrm{O}_{2} \cdot 2 \mathrm{HCl}\right) \mathrm{C}, \mathrm{H}, \mathrm{N}$.

Compounds 14, 16-18 were prepared from $30 \mathrm{~d}$ and the corresponding alkyl halides by using the alkylation procedure described for $31 \mathrm{~d}$ (step1) and the hydrolysis procedure described for compound 10 (step 6).

13-Cyclohexyl-5-iso-propyl-6,7-dihydro-5H-benzo[5,6][1,4]diazepino[7,1-a]indole-10carboxylic Acid (14): mp 220-221 ${ }^{\circ} \mathrm{C} ;{ }^{1} \mathrm{H}$ NMR (300MHz, DMSO-d 6 ) $\delta 8.14$ (s, 1H), 7.85 (d, J = 
8.4 Hz, 1H), 7.61 (d, J = 9.2 Hz, 1H), 7.45-7.35 (m, 1H), 7.35-7.20 (m, 2H), 7.20-7.10 (m, 1H), 4.60-4.00 (m, 5H), 3.70-3.50 (m, 1H), 2.83 (t, J = 12.0 Hz, 1H), 2.10-1.90 (m, 2H), 1.85-1.65 (m, 5H), 1.45-1.20 (m, 3H), 1.06 (brs, 6H); MS (FAB) m/z $403(\mathrm{M}+\mathrm{H})^{+}$; HPLC method A, 98\% (13.9 min); HPLC method B, 96\% (2.63 min).

13-Cyclohexyl-5-benzyl-6,7-dihydro-5H-benzo[5,6][1,4]diazepino[7,1-a]indole-10-carboxylic Acid (16): mp 242-246 ${ }^{\circ} \mathrm{C} ;{ }^{1} \mathrm{H}$ NMR (300MHz, DMSO-d 6 ) $\delta 12.52$ (brs, $\left.1 \mathrm{H}\right), 8.15$ (d, J = $1.5 \mathrm{~Hz}$, $1 \mathrm{H}), 7.88(\mathrm{~d}, \mathrm{~J}=8.8 \mathrm{~Hz}, 1 \mathrm{H}), 7.62(\mathrm{dd}, \mathrm{J}=1.5,8.4 \mathrm{~Hz}, 1 \mathrm{H}), 7.31(\mathrm{t}, \mathrm{J}=6.8 \mathrm{~Hz}, 1 \mathrm{H}), 7.30(\mathrm{~d}, \mathrm{~J}=$ $7.3 \mathrm{~Hz}, 1 \mathrm{H}), 7.19$ (d, J = 7.7 Hz, 1H), 7.13 (d, J = 6.6 Hz, 1H), 7.10-6.95 (m, 5H), 4.45-4.20 (m, 2H), 3.55-3.35 (m, 2H), 3.35-3.25 (m, 2H), 2.83 (brt, J = $12.8 \mathrm{~Hz}, 1 \mathrm{H}), 2.15-1.95(\mathrm{~m}, 2 \mathrm{H})$, 1.90-1.65 (m, 5H), 1.50-1.20 (m, 3H); MS (FAB) m/z $451(\mathrm{M}+\mathrm{H})^{+}$. Anal. $\left(\mathrm{C}_{30} \mathrm{H}_{30} \mathrm{~N}_{2} \mathrm{O}_{2} \cdot 0.2 \mathrm{H}_{2} \mathrm{O}\right) \mathrm{C}$, $\mathrm{H}, \mathrm{N}$.

13-Cyclohexyl-5-(2-phenylethyl)-6,7-dihydro-5H-benzo[5,6][1,4]diazepino[7,1-a]indole-10carboxylic Acid Hydrochloride (17): mp 240-243 ${ }^{\circ} \mathrm{C} ;{ }^{1} \mathrm{H}$ NMR (400MHz, DMSO-d 6 ) $\delta 8.16$ (brs, 1H), $7.87(\mathrm{~d}, \mathrm{~J}=8.3 \mathrm{~Hz}, 1 \mathrm{H}), 7.62(\mathrm{dd}, \mathrm{J}=1.4,8.6 \mathrm{~Hz}, 1 \mathrm{H}), 7.47$ (brt, J = 7.2 Hz, 1H), 7.33 (brd, J $=6.7 \mathrm{~Hz}, 2 \mathrm{H}), 7.25-7.15(\mathrm{~m}, 1 \mathrm{H}), 7.05-6.95(\mathrm{~m}, 5 \mathrm{H}), 5.50-4.25(\mathrm{~m}, 2 \mathrm{H}), 3.62-3.59(\mathrm{~m}, 2 \mathrm{H})$, 3.55-3.10 (m, 3H), $2.83(\mathrm{tt}, \mathrm{J}=3.0,12.0 \mathrm{~Hz}, 1 \mathrm{H}), 2.70-2.55(\mathrm{~m}, 2 \mathrm{H}), 2.10-1.95(\mathrm{~m}, 2 \mathrm{H}), 1.85-1.65$ (m, 5H), 1.45-1.20 (m, 3H); MS (FAB) m/z $451(\mathrm{M}+\mathrm{H})^{+}$. Anal. $\left(\mathrm{C}_{31} \mathrm{H}_{32} \mathrm{~N}_{2} \mathrm{O}_{2} \cdot \mathrm{HCl}\right) \mathrm{C}, \mathrm{H}, \mathrm{N}$.

13-Cyclohexyl-5-(dimethylcarbamoylmethyl)-6,7-dihydro-5H-benzo[5,6][1,4]diazepino[7,1-a]i ndole-10-carboxylic Acid (18): mp 241-245 ${ }^{\circ} \mathrm{C} ;{ }^{1} \mathrm{H}$ NMR (300MHz, DMSO-d 6 ) $\delta 12.46$ (brs, $1 \mathrm{H}$ ), $8.16(\mathrm{~s}, 1 \mathrm{H}), 7.86(\mathrm{~d}, \mathrm{~J}=8.4 \mathrm{~Hz}, 1 \mathrm{H}), 7.61(\mathrm{~d}, \mathrm{~J}=8.4 \mathrm{~Hz}, 1 \mathrm{H}), 7.36(\mathrm{t}, \mathrm{J}=7.9 \mathrm{~Hz}, 1 \mathrm{H}), 7.28(\mathrm{~d}, \mathrm{~J}=$ $7.3 \mathrm{~Hz}, 1 \mathrm{H}), 7.12$ (t, J = 7.3 Hz, 1H), 7.06 (d, J = 8.4 Hz, 1H), 4.60-4.20 (m, 2H), 3.98 (brs, 2H), $3.50(\mathrm{t}, \mathrm{J}=4.7 \mathrm{~Hz}, 2 \mathrm{H}), 2.80(\mathrm{brt}, \mathrm{J}=10.0 \mathrm{~Hz}, 1 \mathrm{H}), 2.74(\mathrm{~s}, 3 \mathrm{H}), 2.71(\mathrm{~s}, 3 \mathrm{H}), 2.10-1.90(\mathrm{~m}, 2 \mathrm{H})$, 1.82-1.70 (m, 5H), 1.45-1.20 (m, 3H); MS (FAB) m/z $446(\mathrm{M}+\mathrm{H})^{+}$. Anal. $\left(\mathrm{C}_{27} \mathrm{H}_{31} \mathrm{~N}_{3} \mathrm{O}_{3}\right) \mathrm{C}, \mathrm{H}, \mathrm{N}$.

13-Cyclohexyl-5-(dimethylaminoethyl)-6,7-dihydro-5H-benzo[5,6][1,4]diazepino[7,1-a]indole10-carboxylic Acid Dihydrochloride (19).

Compound 19 was prepared from $30 \mathrm{~d}$ by using the procedure described for 20 , except $\mathrm{N}, \mathrm{N}$-dimethylamine was employed instead of piperidine: mp $240-244{ }^{\circ} \mathrm{C} ;{ }^{1} \mathrm{H}$ NMR $(400 \mathrm{MHz}$, DMSO-d $\left._{6}\right) \delta 12.51$ (brs, 1H), 10.04 (brs, 1H), 8.18 (d, J = 0.9 Hz, 1H), 7.85 (d, J = 8.6 Hz, 1H), $7.60(\mathrm{dd}, \mathrm{J}=1.3,8.5 \mathrm{~Hz}, 1 \mathrm{H}), 7.50(\mathrm{dt}, \mathrm{J}=1.3,7.7 \mathrm{~Hz}, 1 \mathrm{H}), 7.35(\mathrm{dd}, \mathrm{J}=1.6,7.7 \mathrm{~Hz}, 2 \mathrm{H}), 7.33(\mathrm{~d}$, $\mathrm{J}=7.7 \mathrm{~Hz}, 2 \mathrm{H}), 7.27$ (t, J = 7.3 Hz, 1H), 4.76 (brs, 1H), 3.85-3.40 (m, 6H), 3.20-2.95 (m, 2H), 2.80 (brt, J = $11.0 \mathrm{~Hz}, 1 \mathrm{H}), 2.45(\mathrm{~s}, 3 \mathrm{H}), 2.44(\mathrm{~s}, 3 \mathrm{H}), 2.10-1.95(\mathrm{~m}, 3 \mathrm{H}), 1.90-1.65(\mathrm{~m}, 3 \mathrm{H})$, 
1.50-1.30 (m, 2H), 1.30-1.20 (m, 2H); MS (FAB) m/z $432(\mathrm{M}+\mathrm{H})^{+}$; HPLC method A, 96\% (11.5 min); HPLC method B, 99\% (2.11 min). 


\section{Analytical data}

Elemental Analysis

\begin{tabular}{|c|c|c|c|}
\hline compound & formula & calcd. & found \\
\hline 3 & $\mathrm{C}_{30} \mathrm{H}_{29} \mathrm{NO}_{4}$ & C, 77.07; H6.25; N, 3.00 & $\mathrm{C}, 76.95 ; \mathrm{H}, 6.05 ; \mathrm{N}, 2.73$ \\
\hline 4 & $\mathrm{C}_{23} \mathrm{H}_{23} \mathrm{NO}_{3}$ & C, 76.43; H, 6.41; N, 3.88 & C, 76.32; H, 6.39; N. 3.54 \\
\hline 5 & $\mathrm{C}_{22} \mathrm{H}_{21} \mathrm{NO}_{2}$ & $\mathrm{C}, 79.73 ; \mathrm{H}, 6.39 ; \mathrm{N}, 4.23$ & $\mathrm{C}, 79.46 ; \mathrm{H}, 6.39 ; \mathrm{N}, 3.93$ \\
\hline 6 & $\mathrm{C}_{23} \mathrm{H}_{23} \mathrm{NO}_{2}$ & $\mathrm{C}, 79.97 ; \mathrm{H}, 6.71 ; \mathrm{N}, 4.05$ & $\mathrm{C}, 79.75 ; \mathrm{H}, 6.72 ; \mathrm{N}, 3.78$ \\
\hline 7 & $\mathrm{C}_{24} \mathrm{H}_{25} \mathrm{NO}_{2} \cdot 0.1 \mathrm{H}_{2} \mathrm{O}$ & $\mathrm{C}, 79.79 ; \mathrm{H}, 7.03 ; \mathrm{N}, 3.88$ & $\mathrm{C}, 79.72 ; \mathrm{H}, 7.09 ; \mathrm{N}, 3.53$ \\
\hline 8 & $\mathrm{C}_{22} \mathrm{H}_{21} \mathrm{NO}_{3}$ & C, 76.06; H, 6.09; N, 4.03 & $\mathrm{C}, 75.92 ; \mathrm{H}, 6.18 ; \mathrm{N}, 3.67$ \\
\hline 9 & $\mathrm{C}_{24} \mathrm{H}_{25} \mathrm{NO}_{3}$ & $\mathrm{C}, 76.77 ; \mathrm{H}, 6.71 ; \mathrm{N}, 3.73$ & $\mathrm{C}, 76.88 ; \mathrm{H}, 6.66, \mathrm{~N}, 3.45$ \\
\hline 10 & $\mathrm{C}_{23} \mathrm{H}_{24} \mathrm{~N}_{2} \mathrm{O}_{2} \cdot \mathrm{HCl}$ & $\mathrm{C}, 69.60 ; \mathrm{H}, 6.35 ; \mathrm{N}, 7.06$ & $\mathrm{C}, 69.67 ; \mathrm{H}, 6.41 ; \mathrm{N}, 6.76$ \\
\hline 11 & $\mathrm{C}_{23} \mathrm{H}_{23} \mathrm{NO}_{2} \mathrm{~S}$ & $\mathrm{C}, 73.18 ; \mathrm{H}, 6.14 ; \mathrm{N}, 3.71$ & C, 73.07; H, 6.07; N, 3.45 \\
\hline 15 & $\mathrm{C}_{25} \mathrm{H}_{26} \mathrm{~N}_{2} \mathrm{O}_{3}$ & $\mathrm{C}, 74.60 ; \mathrm{H}, 6.51 ; \mathrm{N}, 6.96$ & $\mathrm{C}, 74.75 ; \mathrm{H}, 6.32 ; \mathrm{N}, 6.67$ \\
\hline 16 & $\mathrm{C}_{30} \mathrm{H}_{30} \mathrm{~N}_{2} \mathrm{O}_{2} \cdot 0.2 \mathrm{H}_{2} \mathrm{O}$ & C, 79.34; H, 6.75; N, 6.17 & C, 79.48; H, 6.73; N, 5.96 \\
\hline 17 & $\mathrm{C}_{31} \mathrm{H}_{32} \mathrm{~N}_{2} \mathrm{O}_{2} \cdot \mathrm{HCl}$ & $\mathrm{C}, 74.31 ; \mathrm{H}, 6.64 ; \mathrm{N}, 5.59$ & $\mathrm{C}, 73.97 ; \mathrm{H}, 6.61 ; \mathrm{N}, 5.34$ \\
\hline 18 & $\mathrm{C}_{27} \mathrm{H}_{31} \mathrm{~N}_{3} \mathrm{O}_{3}$ & C, 72.78; H, 7.01; N, 9.43 & $\mathrm{C}, 72.89 ; \mathrm{H}, 6.85 ; \mathrm{N}, 9.25$ \\
\hline 20 & $\mathrm{C}_{30} \mathrm{H}_{37} \mathrm{~N}_{3} \mathrm{O}_{2} \cdot 2 \mathrm{HCl}$ & $\mathrm{C}, 66.17 ; \mathrm{H}, 7.22 ; \mathrm{N}, 7.72$ & $\mathrm{C}, 66.15 ; \mathrm{H}, 7.49 ; \mathrm{N}, 7.78$ \\
\hline
\end{tabular}

HPLC Analysis

\begin{tabular}{|c|c|c|c|c|}
\hline \multirow{2}{*}{ compound } & \multicolumn{2}{|l|}{ Method A } & \multicolumn{2}{|l|}{ Method B } \\
\hline & Purity (\%) & $\mathrm{Rt}(\min )$ & Purity (\%) & Rt (min) \\
\hline 13 & 97.0 & 16.0 & 95.0 & 2.42 \\
\hline 14 & 97.7 & 13.9 & 95.7 & 2.63 \\
\hline 19 & 95.8 & 11.5 & 99.6 & 2.11 \\
\hline
\end{tabular}




\section{Computational Method.}

We calculated the conformations of the compounds without a carboxylic acid functionality by a random conformational search performed using the MMFF94s force field as implemented in SYBYL 6.9.1 (Tripos Inc., 1669 S. Hanley Road, St. Louis, MO). Random search locates energy minima by randomly adjusting the selected bonds and minimizing the energy of the resulting geometry. Random Search parameters were set to default values with the following exceptions:

MAXIMUM CYCLES = 1000000;

ENERGY CUTOFF $=10.0$;

RMS THRESHOLD $=0.1$;

CONVERGENCE THRESHOLD $=0.005$;

TAILAR!MAXIMIN2!RMS_GRADIENT $=0.005$;

TAILAR!MAXIMIN2!MAXIMUM_ITERATIONS = 10000;

TAILAR!FORCE_FIELD!DIELECTRIC_FUNCTION = CONSTANT;

TAILAR!FORCE_FIELD!NON_BONDED_CUTOFF $=10000.0$;

TAILAR!FORCE_FIELD!FF_CHOICE = MMFF94S.

\section{Crystallization and Data Measurement.}

We have previously constructed and purified a recombinant HCV-BK (1b) NS5B protein with the

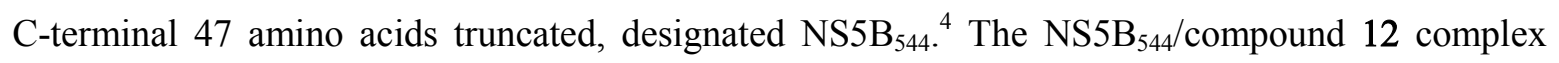
was prepared by soaking the $\mathrm{NS}_{5} \mathrm{~B}_{544}$ crystal in the solution of compound 12. Diffraction data for the complex were collected at KEK/PF NW12. The data collection statistics are summarized as

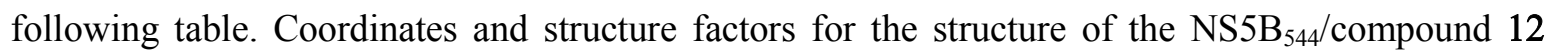
complex have been deposited in the Protein Data Bank (PDB ID 2DXS).

Summary of statistics of a data set and model refinement

\begin{tabular}{ll}
\hline & $\mathrm{NS5B}_{544} /$ compound 12 \\
\hline $\begin{array}{l}\text { Data processing } \\
\text { Space group }\end{array}$ & $\mathrm{P} 2_{1}$ \\
Cell parameters $(\AA)$ & $\mathrm{a}=96.4, \mathrm{~b}=67.2, \mathrm{c}=297.9$ \\
$\quad\left({ }^{\circ}\right)$ & $\beta=93.8$ \\
Resolution $(\AA)$ & $30-2.2$ \\
Completeness $(\%)^{\mathrm{a}}$ & $99.3(98.3)$ \\
No. of reflections (unique) & $224,858(63,257)$
\end{tabular}




$\begin{array}{ll}<\mathrm{I} / \sigma(\mathrm{I})>^{\mathrm{a}} & 10.4(3.3) \\ \mathrm{R}_{\text {merge }}(\%)^{\mathrm{a}} & 12.2(34.0) \\ & \\ \text { Refinement } & \\ \text { Resolution }(\AA) & 30-2.2 \\ \mathrm{R} \text { factor }(\%) & 21.7 \\ \mathrm{R}_{\text {free }}(\%) & 25.9 \\ \text { No. of non-hydrogen atoms } & 8,690 \\ \text { rms deviation } & \\ \quad \text { Bond length }(\AA) & 0.338 \\ \quad \text { Bond angles }\left({ }^{\circ}\right) & 1.7 \\ <\mathrm{B}>\left(\AA^{2}\right) & 30.4\end{array}$

${ }^{\mathrm{a}}$ The number in parentheses refers to the highest resolution shell (2.32 - $\left.2.20 \AA\right)$.

\section{Caco-2 cell experiment}

\section{Cell Culture}

Caco-2 cells (cell passage numbers between 70-99) were seeded onto a fibrillar collagen coated insert (24wells, $0.3 \mathrm{~cm}, 1 \mu \mathrm{M})$ at a density of $2.0 \times 10^{5}$ cells/insert. The cells were grown in culture medium consisting of serum free DMEM with MITO ${ }^{\mathrm{TM}}$ serum extender consisted of EGF, transferring, insulin, ECGS, triiodothyronine, hydrocortisone, progesterone, testosterone, estradiol-17 $\beta$, selenium, and o-phosphoryletanolamine. The culture medium was replaced after $48 \mathrm{~h}$ post-seeding with Entero-STIM (butyric acid containing serum free DMEM). The inserts were placed at $37{ }^{\circ} \mathrm{C}\left(90 \%\right.$ relative humidity and $\left.5 \% \mathrm{CO}_{2}\right)$ for 6 days, and were used for permeability studies.

\section{Permeability study}

Modified Hanks balanced salt solution (MHBS) containing 10 mM HEPES (pH 7.4 and pH 6.5) was used as the transporter medium. Each monolayer was washed twice with MHBS (Donor well, $\mathrm{pH}$ 6.5), and $1 \mathrm{ml}$ of MHBS (receiver well, $\mathrm{pH}$ 7.4) was placed on the basolateral side of the monolayer (receiver well). The permeability studies were initiated by adding $0.3 \mathrm{ml}$ of MHBS containing the compounds. The monolayers were placed on an orbital shaker (50 cycles/min) and incubated for $2 \mathrm{~h}$ at $37{ }^{\circ} \mathrm{C}$. The samples for HPLC analyses were taken from each of the well. Apical to basolateral permeability coefficients were calculated according to the following equation: Permeability coefficients $(\mathrm{Pc})=\mathrm{dA} /\left(\mathrm{dt} \cdot \mathrm{S} \cdot \mathrm{C}_{0}\right)$, where $\mathrm{dA} / \mathrm{dt}$ is the flux of the compound across the 
monolayer $(\mathrm{nmol} / \mathrm{sec}), \mathrm{S}$ is the surface area of the cell monolayer $\left(0.3 \mathrm{~cm}^{2}\right)$, and $\mathrm{C}_{0}$ is the initial compound concentration $(\mu \mathrm{M})$ in the apical compartment. The permeability coefficient values are expressed as $\mathrm{cm} / \mathrm{sec}$.

\section{Analytical Methods}

The concentrations of the compounds were analyzed by a Thermo Finnigan TSQ Quantum HPLC/MS/MS system, using a Waters Xterra C18 column $(3.9 \times 20 \mathrm{~mm}$, solvent system $\mathrm{CH}_{3} \mathrm{CN}-0.1 \%$ formic acid / water- $0.1 \%$ formic acid, gradient $0-95 \%$ over $0.5 \mathrm{~min}, 1 \mathrm{~mL} / \mathrm{min}, 50$ $\left.{ }^{\circ} \mathrm{C}\right)$.

\section{Permeability coefficient values}

Compound 10, $55.9\left(\mathrm{~cm} / \mathrm{sec} * 10^{-6}\right)$; Compound 18, $51.9\left(\mathrm{~cm} / \mathrm{sec} * 10^{-6}\right)$; Compound 19, 19.2 $\left(\mathrm{cm} / \mathrm{sec} * 10^{-6}\right)$; Compound $20,18.6\left(\mathrm{~cm} / \mathrm{sec} * 10^{-6}\right)$.

\section{References}

1. Hirashima, S.; Suzuki, T.; Ishida, T.; Noji, S.; Yata, S.; Ando, I.; Komatsu, M.; Ikeda, S.; Hashimoto, H. Benzimidazole derivatives bearing substituted biphenyls as Hepatitis $\mathrm{C}$ virus NS5B RNA-dependent RNA polymerase inhibitors: Structure-activity relationship studies and identification of a potent and highly selective inhibitor JTK-109. J. Med. Chem. 2006, 49, 4721-4736.

2. Compounds 21 and 25 were prepared according to the following patent application: Beaulieu, P. L.; Fazal, G.; Kukolj, G.; Jolicoeur, E; Gillard, J; Poupart, M.-A.; Rancourt, J. Viral polymerase inhibitors. Int. Patent Apply WO03/010140.

3. Compound $26 \mathrm{~b}$ was prepared according to the following paper: Kozikoski, A. P.; Ma, D. Palladium catalyzed synthesis of annelated indoles. Tetrahedron Lett. 1991, 32, 3317-3320.

4. Adachi, T.; Ago, H.; Habuka, N.; Okuda, K.; Komatsu, M.; Ikeda, S.; Yatsunami, K. Biochim. Biophys. Acta 2002, 1601, 38-48. 